\title{
Perception of population ageing and age discrimination across EU countries
}

\author{
Jitka Rychtaříková ${ }^{1}$ \\ 1 Charles University, Prague, 128 43, Czech Republic
}

Received 12 August 2019 • Accepted 25 November 2019 Published 30 December 2019

Citation: Rychtaříková J (2019) Perception of population ageing and age discrimination across EU countries. Population and Economics 3(4): 1-29. https://doi.org/10.3897/popecon.3.e49760

\begin{abstract}
Population ageing is the most dominant demographic challenge that the European Union is experiencing in the $21^{\text {st }}$ century. This may create negative attitudes and lead to discrimination against persons of advanced age. Age-related stereotypes and prejudice can result in age discrimination, termed ageism. This research concerns the question of perceived ageism towards older people in $25 \mathrm{EU}$ countries, surveyed in 2015 using the Special Eurobarometer 437. The analytical section includes descriptive findings and the results of three multi-level regression models addressing three domains (explained variables) of perceived ageism: 1) discrimination in general, 2) discrimination during economic crisis, and 3) discrimination when electing an older person as a high official. The two-level regression allowed simultaneous modelling of individual-level (gender, age, partnership status, social class, and life satisfaction) and of country-level (life expectancy at 55, perceived start of old age, and HDI) effects. The personal characteristics impacted much stronger perceived ageism than country contexts. Ageist perception in general has mostly been noted at pre-retirement age, but the age profile has not been the same across three regression models. The East-West gradient, frequently reported, is questioned because the geographical picture of perceived ageism is rather puzzling.
\end{abstract}

\section{Key words}

population ageing, perceived ageism, age discrimination, European Union

JEL codes J11, J14, J16

\section{Population ageing: a major challenge for the $21^{\text {st }}$ century}

The objective of the study is twofold: firstly, to describe briefly the main trends related to population ageing and, secondly, as the key point, to address the theme of old age discrimination in Europe. 
The size and age composition of a population are determined by three demographic processes: fertility, mortality and migration. The change in age structure when the proportion of people aged 60 or 65 and over is increasing is called population ageing. In developed countries the age of 65 years is referred to as 'old age', because retirement schemes typically consider this age as the 'normal' retirement age. Declining fertility and increasing longevity are key drivers of population ageing, while migration contributes to this phenomenon to a lesser extent. Population ageing is the most dominant demographic challenge that the European Union is experiencing in the $21^{\text {st }}$ century. The social and economic implications of such a historically unprecedented development will affect everybody. The shift in age structure raises concerns about the long-term viability of intergenerational social support systems: as more people live longer, retirement, pensions and other social benefits tend to extend over longer periods of time, making it necessary for social security systems to change substantially to remain effective. Increasing longevity can also result in rising medical costs and in increasing demands for health services, since older people are typically more vulnerable to chronic diseases (The 2018 Ageing Report). This may result in negative attitudes and cause discrimination against persons of advanced age. However, recent research shows that advances in life expectancy have also led to improvements in health. Older people today tend to have fewer disabilities compared to people of the same age in earlier decades, and there is evidence suggesting that cognitive decline is being postponed (Sanderson and Scherbov 2008). Consequently, the meaning of years to be lived has changed over time in terms of quantity and quality. Measuring population ageing (percentage of population aged 65 years and over) is based on chronological (retrospective) age, i.e. on the number of years already lived (when assuming all persons of the same age are similar). Such an approach is indicated as backward-looking (Sanderson and Scherbov 2007). A new concept of age, based on the number of years expected to be lived (prospective age), represents a forward-looking measure, which enables to re-evaluate the process and speed of population ageing. When measuring ageing is based on people's time left until death, faster increases in human life expectancy could even lead to slower population ageing (Sanderson and Scherbov 2015). This new concept can be applied when calculating old age dependency ratios. The conventional approach usually defines an old age dependency ratio (OADR) as the ratio of people aged 65 or older to the people aged 20-64 and uses the age of 65 as the fixed start age of 'dependency', even though people aged 65+ mostly live independent and active lives. New (prospective) age interpretation allows to express prospective old age dependency ratio (POADR) as the ratio where the onset of dependency is dynamic and country specific, and which is based on the number of years expected to live (currently 15 years). Therefore, POADR is the ratio of the number of people above the old-age threshold to the number of people from age 20 to the old-age threshold (Sanderson and Scherbov 2008).

At present, almost every country is experiencing growth in the number and proportion of older persons in their population. The share of older persons in the total population will further increase significantly in the coming decades. Looking back in history, no country had more than $11 \%$ of its population aged 65 and over, apart from in 1950, but in 2018 the highest figures already amounted to $27.6 \%$ in Japan and $22.8 \%$ in Italy (UN 2019). The phenomenon of population ageing is expected to be irreversible and to occur in all populations; however, the magnitude and speed at which it will take place may vary. Decreasing fertility rates were the primary cause of population ageing. The decline of fertility below replacement level (2.1 live born children per woman) started for most current EU countries in the mid1960s, while critical fertility levels (total fertility rate below 1.5 or even less than 1.3) have 
appeared more recently (primarily starting in the 1990s) in Southern and former Eastern European countries. Declines in mortality rates were first greater at young ages, which resulted in a rejuvenation of the age structure. Only when the larger cohorts moved up the age pyramid and mortality improvements at older ages became substantial (primarily related to the change termed cardiovascular revolution defined as the decrease of cardiovascular mortality), mortality decline was recognized as another driver of population ageing (Meslé and Vallin 2000). Population ageing related to the shrinking number of live births at the bottom of the age pyramid is called ageing from the bottom, while mortality rate reduction, due to the decrease in older age, is referred to as ageing from the top (Monnier 2006).

The population of the EU-28 on 1 January 2018 was estimated at 512.4 million. Young people (0 to 14 years old) made up $15.6 \%$ of the EU-28's population, while persons considered to be of working age (15 to 64 years old) accounted for $64.7 \%$ of the population. Older persons (aged 65 or over) had a $19.7 \%$ share. Consequently, Europe is and will remain the world's oldest region throughout the $21^{\text {st }}$ century. Moreover, the older population itself is ageing and the oldest-old (aged 80+) represent the fastest growing age group (Eurostat Database). Across the EU member states the highest share of people aged 65 and older was observed on 1 January 2018 in Italy (22.6\%) and Greece (21.8\%), while Ireland (13.8\%) and Slovakia (15.5\%) had the lowest percentages (Figure 1).

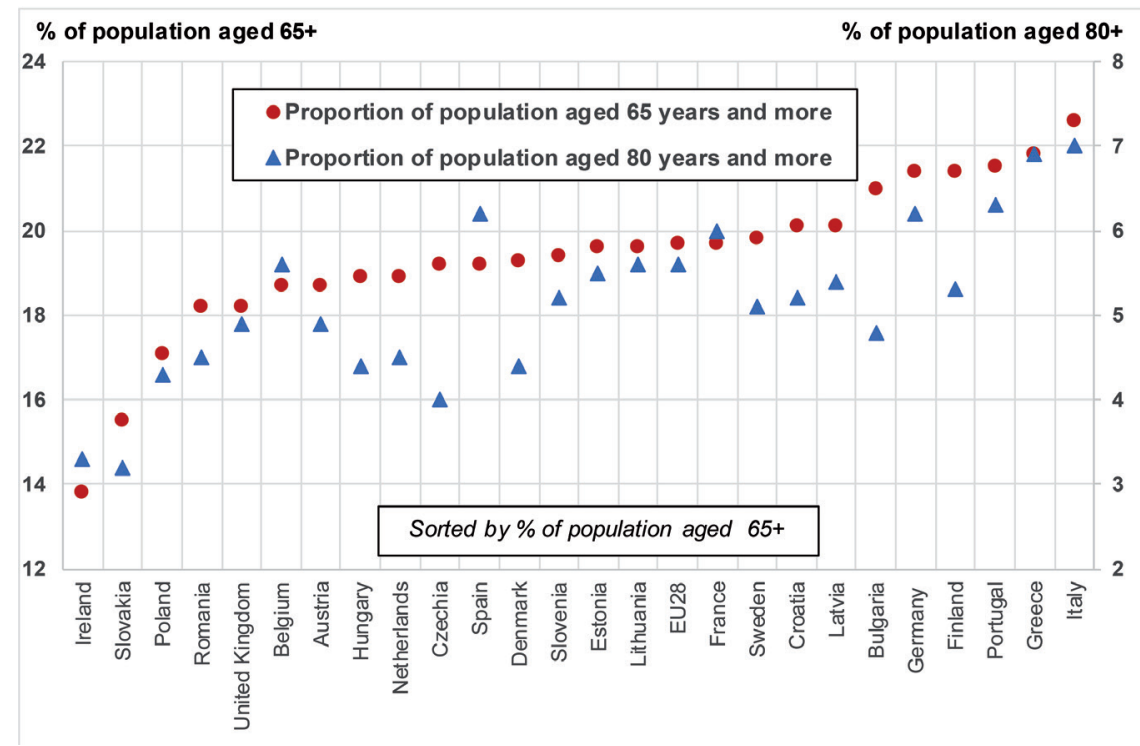

Figure 1. The share of population of 65 years and older and 80 years and older 1.1.2018 (\% of total population of a respective country). Source: EUROSTAT; EU countries having more than one million inhabitants.

Figure 2 shows and highlights the difference between conventional (retrospective) old age dependency ratio (OADR: $65+/ 20-64$ ) and prospective old age dependency ratio (POADR: old-age threshold+ / 20 - old-age threshold) in the year 2015. The most pronounced differences between OADR and POADR can be seen for Italy, France, and Finland (17 percentage points). This new approach shows lower values of ageing indicators based on prospective 
age. Therefore, it initiates rethinking and re-evaluating of the issue of population ageing including the specification of retirement age or needs for health and social services (Ageing Demographic Data Sheet 2018).

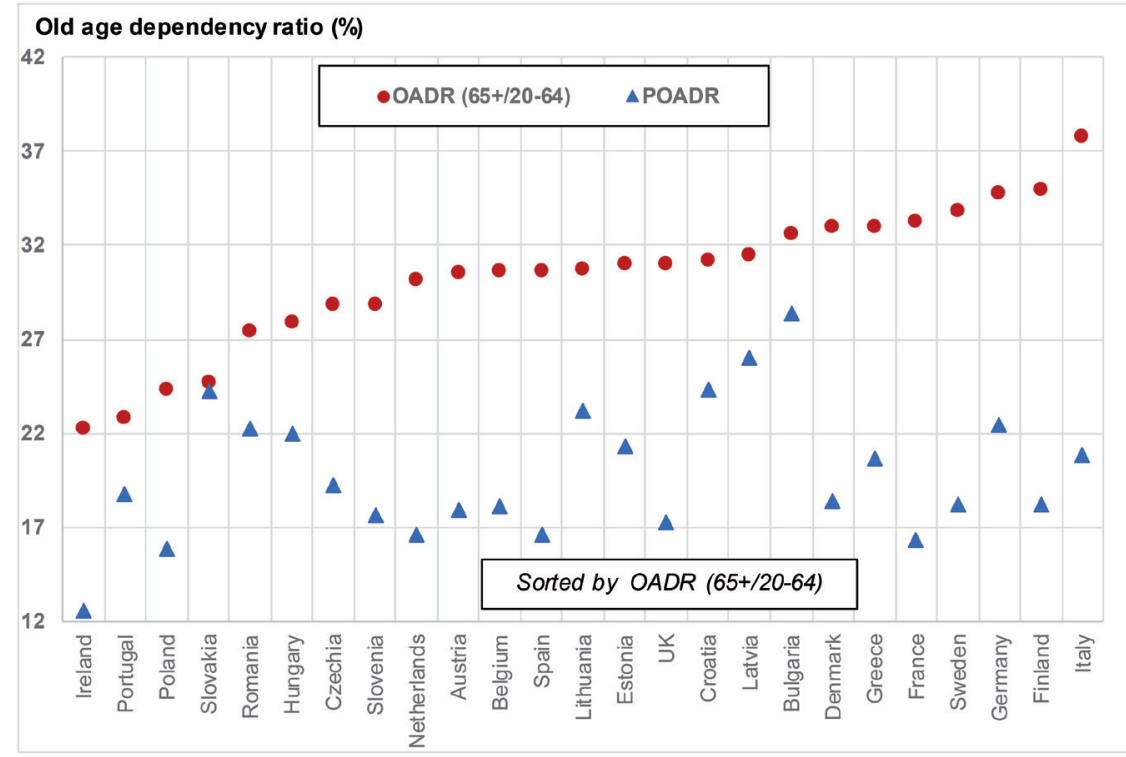

Figure 2. Old-age dependency ratio (OADR) compared with prospective old-age dependency ratio (POADR) in 2015. Source: Aging Demographic Data Sheet 2018. IIASA: Laxenburg, Austria; EU countries having more than one million inhabitants

\section{Ageing and Ageism: Perceptions and Origins}

The experience of intense population ageing is historically new and brings new challenges including people's perception and expectations about older people. This new experience might create negative attitudes and lead to discrimination against persons of advanced age. Research shows that age, together with gender, are the most frequently mentioned reasons for discrimination in the EU (van den Heuvel and van Santvoort 2011). Perceptions of old age influence societal behavior and expectations towards the elderly (Lockenhof et al. 2009). This perception can vary from one society to another and it can change over time within any given society. Old age is often associated with negative representations of illness, disability and low status, which have important consequences for people as they grow older in different domains of life: at work, in public spaces, in shops, or in doctors' offices (Ayalon and Tesch-Römer 2018). Furthermore, in contemporary societies of developed countries, the perception of old age and ageing is mostly unfavourable and older people are often regarded as a non-contributing burden (Nelson 2005). The implementation of governmental or private pension programs provide economic protection and improving living standards for the elderly, but paradoxically at the same time it reinforces the perception of the aged as irrelevant, obsolete, useless and unimportant (Dannefer and Shura 2009). These negative values provide a justification for their social marginalization and exclusion. In the past how- 
ever, the status of the elderly was different. According to Livi Bacci, 'The old demographic regime was characterized not only by inefficiency but also by disorder' (Livi-Bacci 2001: 119). Before the first demographic transition, death was not correlated with old age, as the probability of a child dying before its parents or grandparents was considerable. In these traditional societies, only few individuals enjoyed a long life, who were therefore credited for their longevity. Later, in modern societies, medical progress and technological advances led to increased longevity and the rise in the number of older people. Shifts in the labour market due to industrialization preferred younger strong workers and the status of older people started to decline. The loss of status of older workers in globalised economies is based on the demands of a global labour market in which cost-efficiency, flexibility, adaptability and transferable skills are required (Stypińska and Nikander 2018). The current low status of old age is moreover aggravated by lower levels of education in older generations and their 'obsolete' knowledge (Dannefer and Shura 2009). Older employees are often viewed as harder to train or retrain, more expensive because of higher salaries and as using more health care benefits. These historical changes are articulated in the macro-level Modernization Theory, which postulates the loss of social status of the elderly in modern times (as compared to pre-modern eras) through the shift towards industrialized production, including advancements in technology and medicine. It also describes the devaluation of experience-based knowledge of older adults (Ayalon and Tesch-Römer 2018). In addition, as younger people move to cities, the contact between generations declines and increased secularization further reduces family ties (Ayalon and Tesch-Römer 2018). However, there is hope that the baby boom birth cohorts will not tolerate this negative, even almost normative perception of the elderly. Instead, they are expected to live a more active, productive and successful lifestyle that may be referred to as 'innovative ageing' (Dannefer and Shura 2009).

Getting older today is often viewed as a biological process of senescence due to the gradual deterioration of body and to some degree it is also seen as a limitation of mental functions. This is manifested, in general, by an increasing risk of morbidity and mortality with age. Consequently, there is a stereotyping belief that old age is a uniform stage of the end of life when people are mostly sick, dependent, weak, incompetent, poor or lonely. Older people are consequently considered as one homogeneous group despite their diverse living situations.

Research showed that age related cognitive changes start usually after the age of 85 (Pasupathi and Löckenhoff 2002). Nevertheless, younger people seem to adopt ageist attitudes and distance themselves from older people, due to the association of old age with death and incompetence. According to the micro-level Terror management Theory (TMT), the elderly serves as a reminder of one's own vulnerability and mortality and thus individuals attempt to create a buffer against death-related anxiety (Ayalon and Tesch-Römer 2018). The recent spatial and cultural separation between age groups in society lead to negative feelings or ignorance between respective groups and thus contributes to development of stereotypes and prejudice. Contact between those aged more than 65 and young adults or children becomes rarer in contrast to the past (Hagestad and Uhlenberg 2006). This age segregation between the young and the old can create hostile reactions towards an outgroup, which can be explained with the Intergroup Threat Theory (also Integrated Threat Theory) (Ayalon and Tesch-Römer 2018) or the Intergenerational Conflict Theory (North and Fiske 2013). These theories are based on the three expectations, which younger generations commonly have about of generations: (1) succession of resources from the older to the younger, (2) limiting elderly participation in activities usually reserved for younger people, and (3) minimal con- 
sumption of shared resources by older generations. Often, people are more likely to identify with an own group and to defend its status against outgroups. This social identification is subject of the micro-level Social Identity Theory (SIT) (Ayalon and Tesch-Römer 2018).

Age stereotypes and prejudice can result in age discrimination, termed ageism (Kotter-Grühn 2015). Before age-related discrimination gained interest in the mid-1960s, most attention focused on racism (primarily in the USA) and sexism (Palmore 1999; Ayalon and Tesch-Römer 2018). Unlike race and sex (fixed at birth, constant throughout life, and not applying to everybody), becoming old is a part of everybody's life course, everybody will experience this last phase of life and hence be at risk of ageism.

Looking back in history, definitions and concepts of ageism have changed over time. R. Butler was the first to introduce the term ageism (Butler 1969: 243) ${ }^{1}$. He wrote later (Butler 1980) 'There are three distinguishable yet interrelated aspects to the problem of ageism: 1) Prejudicial attitudes toward the aged, toward old age, and toward the aging process, including attitudes held by the elderly themselves; 2) discriminatory practices against the elderly, particularly in employment, but in other social roles as well; and 3) institutional practices and policies which, often without malice, perpetuate stereotypic beliefs about the elderly, reduce their opportunities for a satisfactory life and undermine their personal dignity. All three have contributed to the transformation of aging from a natural process into a social problem in which the elderly individual bears the detrimental consequences.' Nowadays, a more general definition is used; ageism is defined as prejudice or discrimination against or in favour of any age group. In this contribution the term ageism is devoted to ageism towards older adults.

Perceptions of ageing and ageism are multi-dimensional and can encompass both positive and negative views. The notion of positive and negative ageism was first introduced by E. Palmore in 1999. He defined nine major stereotypes that reflect negative prejudice toward old people: illness, impotency, ugliness, mental decline, mental illness, uselessness, isolation, poverty, and depression. Positive ageism is less common; E. Palmore listed eight major positive stereotypes: kindness, wisdom, dependability, affluence, political power, freedom, eternal youth, and happiness. The combination of negative and positive stereotypes is summarised in the Stereotype Content Model (SCM) proposed in 2002 (Fiske et al. 2002; Cuddy et al. 2005). The SCM hypothesises that stereotypes could be classified along two dimensions: warmth and competence. The combination of both dimensions creates four modalities: a) Pity: high warmth + low competence; b) Envy: high competence + low warmth; c) Admiration: high warmth + high competence; d) Contempt: low warmth + low competence). A mixture model of low competence ('pity') combined with high warmth corresponds to 'pseudopositive' attitudes of older people (Nelson 2005) and consequently constructs a paternalistic stereotype, i.e. not letting people take responsibility for their own lives (Fiske et al. 2002; Cuddy et al. 2005). Positive or negative age stereotypes held by older individuals can have beneficial or detrimental effects on a variety of cognitive and physical outcomes. The Stereotype Embodiment Theory states that lifetime exposure to ageist stereotypes leads to self-ageism. These negative old age stereotypes, which the older adults may adopt regarding their own age group, may then exert an adverse influence on health amongst them (Levy 2003).

\footnotetext{
Ageism describes the subjective experience implied in the popular notion of the generation gap. Prejudice of the middle-aged against the old in this instance, and against the young in others, is a serious national problem. Ageism reflects a deep-seated uneasiness on the part of the young and middle-aged-a personal revulsion to and distaste for growing old, disease, disability; and fear of powerlessness, "uselessness," and death
} 
The next analytical section addresses perceived ageism towards older people in $25 \mathrm{EU}$ countries from three perspectives: a) Perception of discrimination in general, b) Age discrimination in hard economic times, c) Age prejudice against old age high officials. The results are discussed within the framework of above theories and other research.

\section{Ageism in EU: Materials and Methods}

People's attitudes and stereotypes are formed at individual as well as at societal levels. Individual characteristics such as gender, age, socio-economic status etc. can influence one's way of judging people. Societal context can shape the attitudes towards old age. Since Europe is diverse regarding its political, socio-economic and cultural contexts, it is important to explore the impact of country differences, besides individual characteristics. The study of differentiation between macro-(country) and micro-(individual) level predictors provides information on how much of variability in ageist statements is due to country socio-cultural contexts and what extent can be attributed to individual differences.

The present research primarily concerns the question of perceived ageism towards older people; therefore, we do not explore experienced ageism. Perceived discrimination is the perception of being treated unfairly by others because of personal attributes and also due to country contexts. Data primarily come from 25 countries of EU surveyed in 2015 with the Special Eurobarometer 437 (Malta, Cyprus and Luxembourg were omitted because of their small population size, which might reflect a special social climate). The respondents represent the resident population aged 15 years and over. ${ }^{2}$ The Eurobarometer data represent the most recent international dataset ${ }^{3}$, which includes information on ageism, as well as attitudes towards sexism, racism, LGBT, etc. Respondents were informed about the definition of discrimination being that a person or group is treated less favourably than others because of personal characteristics. The number of respondents from 25 countries (at about one thousand in each country) was restricted to completely filled cases. Exclusion of unspecified individual socio-economic characteristics slightly reduced the original sample (see Annex II). Further reduction was due to the 'don't know' category. The final number of observations for three types of discrimination was as follows: 23872 (Perception of discrimination in general); 22421 (Age discrimination in hard economic times); and 22728 (Age prejudice against old age high officials).

In order to grasp the contextual differences between countries, relevant country-level variables were collected independently from the Eurobarometer survey data. Available macro-level statistics often reflect shared underlying factors (for example a degree of economic development). Our aim was to select relevant macro-indicators that could provide unique information and that were statistically significant in at least one of three final regression models. We first selected the following macro-level indicators: proportion of population aged 55 and over, prospective proportion old, life expectancy at age 55 for both sexes, perceived start of old age, old-age dependency ratio (OADR), prospective old-age dependency ratio (POADR), Gross Domestic Product per capita in Purchasing Power Standards (GDP PPS), Gini coefficient, Active Ageing Index (AAI), Human Development Index (HDI), and Human Life Indicator (HLI). The results of bivariate correlations of the above mentioned

\footnotetext{
Methodology and technical specification of the survey can be found in the Special Eurobarometer 437 report.

3 Previous studies mostly used data from European Social Survey 2008, Round 4.
} 
indicators with three variables are: a) percentage of people answering that discrimination on the basis of being over 55 years old is very or fairly widespread, b) percentage of people stating that to tackle the economic crisis, people aged 55 and over should be excluded from recovery measures (answer = yes definitely), c) percentage of people saying that they would not feel comfortable at all having a person over 75 years of age in the highest elected political position, showed that the strongest correlations are for life expectancy at age of 55 for both sexes, perceived start of old age, and Human Development Index.

- Life expectancy at age 55 measures the number of years expected to be lived by a person at the exact age of 55. The indicator also provides clues on the health situation of adult seniors in a country. The threshold of 55 years was selected, because of the information on discrimination focused on people aged 55 or older provided by the Eurobarometer (437) survey. Life expectancy at age 55 was taken from the Human Mortality Database for the year 2015.

- Perceived start of old age was used as the indicator of age self-categorisation. This indicator was selected instead of the conventional official retirement age, because people consider themselves as part of a certain age group. Older people can internalise negative stereotypes, which might harm their physical and mental health later on. Data were taken from Special Eurobarometer 378 and are related to the year 2012.

- Human development index (HDI) is a summary measure of average achievement in key dimensions of human development (a long and healthy life, being knowledgeable, and having a decent standard of living) of a country, not considering economic level alone. HDI does not reflect on inequalities, poverty, human security, empowerment, etc. The data refer to the year 2015 (Human Development Report 2016) and all countries belong to the group indicated as very high human development.

The three selected country macro-indicators were then linked with the following micro-level survey data. For regression modelling the individual (micro)-level variables were transformed into categorical variables with the use of the subsequent reference-coding scheme; reference categories are in bold:

- Gender (females compared to males with males as reference category). Women are at risk of gendered ageism, a double jeopardy where discrimination due to both age and gender leads to increased vulnerability (Krekula et al. 2018). Consequently, we can hypothesize that women will be in a more marginalized position compared to men.

- Age (15-24 (ref), 25-34, 35-44, 45-54, 55-64, 65-74, 75+). Age is generally perceived as an indicator of abilities, competence, skills, etc. The age category also shows to what extent people express their ageist attitudes. Members of any stigmatized group (elderly) can expect to be seen negatively by others and internalize these negative stereotypes (Vauclair et al. 2016). It is therefore expected that higher ages correspond to more widespread perceived discrimination.

- Partnership status (re-)married/single with partner (ref), divorced or separated, widowed, single). Many older adults suffer from loneliness, which can have detrimental effects on physical and mental health. Older people living without a partner can experience a lack of social relationships and interactions, and therefore become marginalized or downgraded (Shiovitz-Ezra et al. 2018).

- Social class (middle class (ref), working class, lower middle class, upper middle class, higher class). In later life, people often transition into lower social status groups, which can affect their psychological health and therefore increase the occurrence of anxiety and depression (Green and Benzeval 2010). Enforced feelings of old age discrimina- 
tion have been primarily observed in former manual workers. Socio-economic status or social class and educational level are correlated. Social class expresses a person's current position in society, while education may be less precise in this regard. For this reason, we have chosen social class for our analysis.

- Life satisfaction (very satisfied (ref), fairly satisfied, not very satisfied, not at all satisfied). Higher levels of perceived discrimination are usually associated with lower life satisfaction, even after controlling for age, gender and other factors (Kim and Kang 2017).

Three regression models address three different types of perceived discrimination against older people and are specified with the following outcome variables: 1) discrimination in general against 55+, 2) discrimination during economic crisis against 55+, and 3) discrimination when electing an old person $(75+)$ as a high official. The independent variables are the same for all three models: at individual level- categorical predictors- (gender, age, partnership status, social class, and life satisfaction) and at country level- covariates- (human development index, life expectancy at age 55, perceived start of old age). Multi-level modelling is suitable when data are grouped (clustered), because individual attitudes can be affected by a country context (Singer 1998; Bell et al. 2013). This method also allows simultaneous modelling of individual-level and country-level effects. Thus, perceived discrimination is a result of individual characteristics, as well as some national-level variables.

To model these effects SAS 9.4 software was used (Linear Mixed Models - LMM, proc mixed). In order to maximize the explanatory power, the predictors were restricted to those that were most central theoretically and statistically significant. Categorized individual (micro)-level predictors and continuous country (macro)- level predictors transformed into $\mathrm{Z}$-scores were used for parameter estimates. Interaction terms were not statistically significant and therefore the model is limited to main effects only. A two-level model (level $1=$ respondents, level 2 = countries) with random intercept (intercepts are permitted to vary by country) was applied. The decision was supported by the fact that when trying to perform random intercept and random slope modelling, only intercept random effects were statistically significant, while all slope effects were insignificant. To estimate parameters, maximum likelihood (ML) was used, which is better for unbalanced data. All three regressions start with an 'unconditional' or means-only model and then the following variables are added: 1) macro-level predictors, 2) micro-level variables, 3) both macro and micro indicators, and 4) final model consists of only significant predictors. Intraclass Correlation Coefficient (ICC: the ratio of the between-cluster variance to the total variance) shows how much of the overall variation in the response is explained by countries. Intraclass correlation takes values from 0 to $1 .{ }^{4}$ A country-level dataset with relevant country variables is included as Table Annex I and individual-level descriptions are stated in Table Annex II.

Three different indicators of perceived discrimination against older people are included as outcome variables in multilevel regression models:

- Perception of discrimination in general, answering to what extent discrimination is widespread. Question: Could you please tell me whether, in your opinion a discrimination on the basis of being over 55 years old is very widespread, fairly widespread, fairly rare or very rare in your country? Coding: $1=$ non-existent, $2=$ very rare, $3=$ fairly rare, $4=$ fairly widespread, $5=$ very widespread. $\mathrm{N}=23872$

\footnotetext{
4 If all the observations are independent of one another, the ICC equals 0 . At the other extreme, if all the responses from observations in all clusters are exactly the same, the ICC equals 1. Because in all our unconditional models the ICC > 0.05, multilevel approach is suitable to use.
} 
- Whether a discrimination should be practised to people being over 55 years old during hard times/economic crisis. Question: Do you think that measures to fight the economic crisis and policies to promote recovery are excluding people aged 55 and over? Coding: $1=$ No, definitely not, $2=$ No, not really, $3=$ Yes, to some extent, $4=$ Yes, definitely. $\mathrm{N}=22421$

- To what extent discrimination occurs when electing a person over 75 years old to the highest political position. Question: Using a scale from 1 to 10, please tell me how you would feel about having a person over 75 years old in the highest elected political position? Coding: $1=$ totally comfortable, $2,3, \ldots \ldots \ldots 7,8,9,10=$ not at all comfortable. $\mathrm{N}=22728$

In contrast to the original coding, the codes were rearranged in the same direction: going from lower discrimination (low values) towards higher discrimination (higher values). Answers DK (don't know) were excluded, resulting in slightly different numbers of respondents for each of the three above mentioned models.

The analytical section first includes descriptive findings and then presents the results of the multi-level regression modelling in the second part.

\section{Ageism in EU: Descriptive findings}

The distribution of three different types of perceived discrimination against old people across 25 EU countries have been examined: a) Perception of discrimination in general, b) Age discrimination in hard economic times, c) Age prejudice against old age high officials.

a) Perception of discrimination in general

The Figure 3 shows a ranking of 25 EU countries according to the general perception of discrimination against people 55+ years old. The proportion of people, who think that discrimination against people aged 55 or more is very or fairly widespread, varies from $63.1 \%$ in Bulgaria (Czechia $60.3 \%$ ) to $23.6 \%$ in Denmark.

Often, differences in values and beliefs are inferred from broad classification into 'Eastern' versus 'Western Europe. This cannot be applied here, because Denmark and Poland show weak ageist attitudes (Figure 3). On the contrary, France (typical Western country) ranks, according to the survey results, among 'ageist' countries along with most former socialist countries. At the same time, all of the above-mentioned countries show different degrees of population ageing (Figure 1). The situation is a little peculiar in post-socialist countries, where perception of age discrimination is relatively high (Figure 3 ), despite having a very low proportion of people aged $65+$ and $80+$ (Figure 1 ). This result could be explained by anticipatory behaviour (possibly disseminated by mass media). Due to the recent pronounced fertility decline, population ageing will be rapid in the region in the near future. Given the fact that the population dependency ratio has significantly increased across advanced economies, terms such as 'demographic crisis, demographic panic or demographic time-bomb' have appeared (Mullan 2002). In a situation of rapid population ageing, ageist attitudes could strengthen, as people might form their prejudice based on fear for their own future material living conditions. Such thinking can sometimes be spread by mass media, which play a major role in shaping public opinion nowadays. 'Visual ageism' frequently portrays older adults as peripheral or minor societal groups without positive attributes and as an over-homogenized community (Loos and Ivan 2018). In addition, quite often, only 'technical' macroeconomic analyses of the costs 


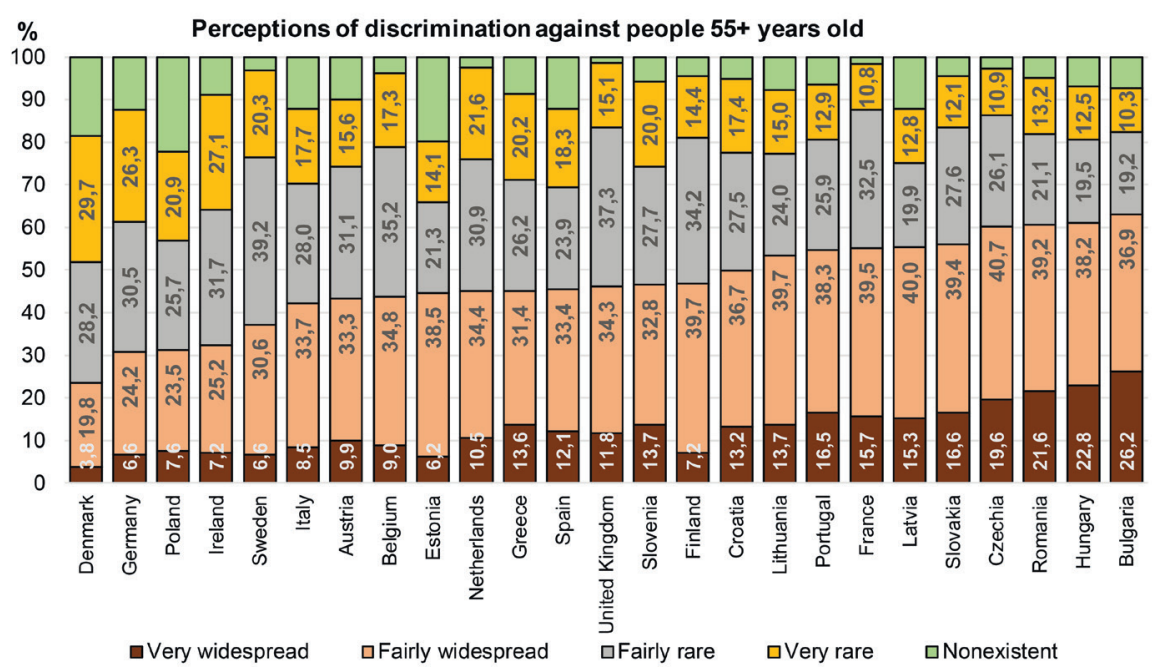

Figure 3. Perception of discrimination in general Sorted according to "very widespread"+"fairly widespread" N=23 872.

Question: Could you please tell me whether, in your opinion a discrimination on the basis of being over 55 years old is very widespread, fairly widespread, fairly rare or very rare in your country? Coding: 5 =very widespread, $4=$ fairly widespread, 3 = fairly rare, 2 =very rare, $1=$ =non-existent. Source: Special Eurobarometer 437

of ageing and the rise in age-related expenditures (pensions, health care, long-term care) are presented, like in the Ageing Reports published by European Commission (The 2018 Ageing Report).

b) Age discrimination in hard economic times

Ageism, primarily at work, can emerge strongly during economic crises. Older employees may be perceived as more expensive and less efficient than their younger counterparts, which might exacerbate the crisis further.

During difficult economic times, intensified discrimination can occur in the recruitment process by refusing to hire an older person or by making someone redundant because of his or her age. This type of discrimination where older workers for instance are paid less than younger workers are or are left out of promotions, is referred to as hard discrimination. Soft discrimination consists of practices that occur in the interpersonal sphere, such as ageist jokes or remarks, receiving lower evaluation of work, being treated disrespectfully, etc. (Stypińska and Nikander 2018).

Figure 4 shows country location based on age discrimination related to measures eventually taken during hard economic times against people aged 55 and more. Increased ageist attitudes related to hard economic conditions are especially seen in countries with higher levels of unemployment. In 2015, the unemployment rate (Unemployment statistics 2019) percentage of unemployed persons out of the labour force, ages 15-74 in 2015was $20 \%$ in Spain and $23 \%$ in Greece. The coefficient of correlation, between the statement that people aged 55 and over should be excluded from the measures combating economic crisis (answer Yes, definitely) and the unemployment rate, was 0.616 in 2015 for 25 above examined countries. 


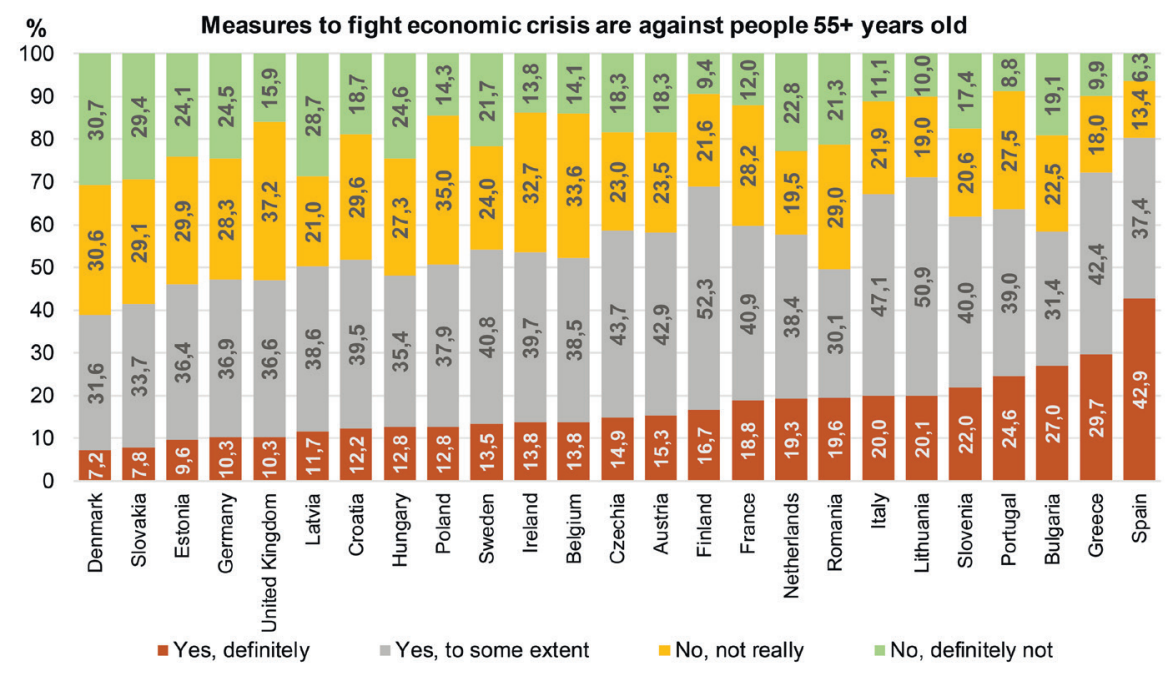

Figure 4. Discrimination against people aged 55+ during economic crisis Sorted according to yes definitely $\mathrm{N}=22421$

Question: Do you think that measures to fight the economic crisis and policies to promote recovery are excluding people aged 55 and over?

Coding: $4=$ Yes, definitely $3=$ Yes, to some extent, $2=$ No, not really $1=$ No, definitely not.

Source: Special Eurobarometer 437

c) Age prejudice against old age high officials

Some older adults retain outstanding cognitive function well into their 70 s and 80 s. In general, speech and language processing are good in older adults under normal conditions and they may even have a more extensive vocabulary compared to younger people (Glisky 2007). However, executive cognitive function involving decision making, problem solving, planning and multitasking seem to decline with advancing age (Murman 2015). Older adults rely more on prior knowledge about the problem domain and less on new information. Nevertheless, cognitive functions vary greatly across individuals.

Six former socialist countries (Lithuania, Latvia, Romania, Bulgaria, Czechia, Slovakia, and Slovenia) appear to be unwilling to have an old person in the highest political position (Figure 5). This result is in accordance with the first four countries, where the current presidents are indeed not very old, in Czechia on the contrary, the president was 71 years old in 2015 and has since been re-elected for the second time by direct election. In contrast, $48 \%$ respondents in Ireland and almost $40 \%$ in United Kingdom seem to be totally comfortable with officials in a high political position aged 75 or older. Interestingly, Denmark's position as the least discriminatory country has changed greatly towards to preferring younger politicians.

To summarize the descriptive findings related to three different types of perceived discrimination: a) against elders in general, b) during hard economic times, and c) against old people in high political position, we conclude that an increased expression of age discrimination is more noticeable in the former socialist countries with the exception of Poland. Concerning 'Western' Europe, the picture is more ambiguous; while Denmark held nonageist position for the first two questions only, the ranking of the United Kingdom or Italy was variable across the discrimination types. For a further in-depth investigation of matters 


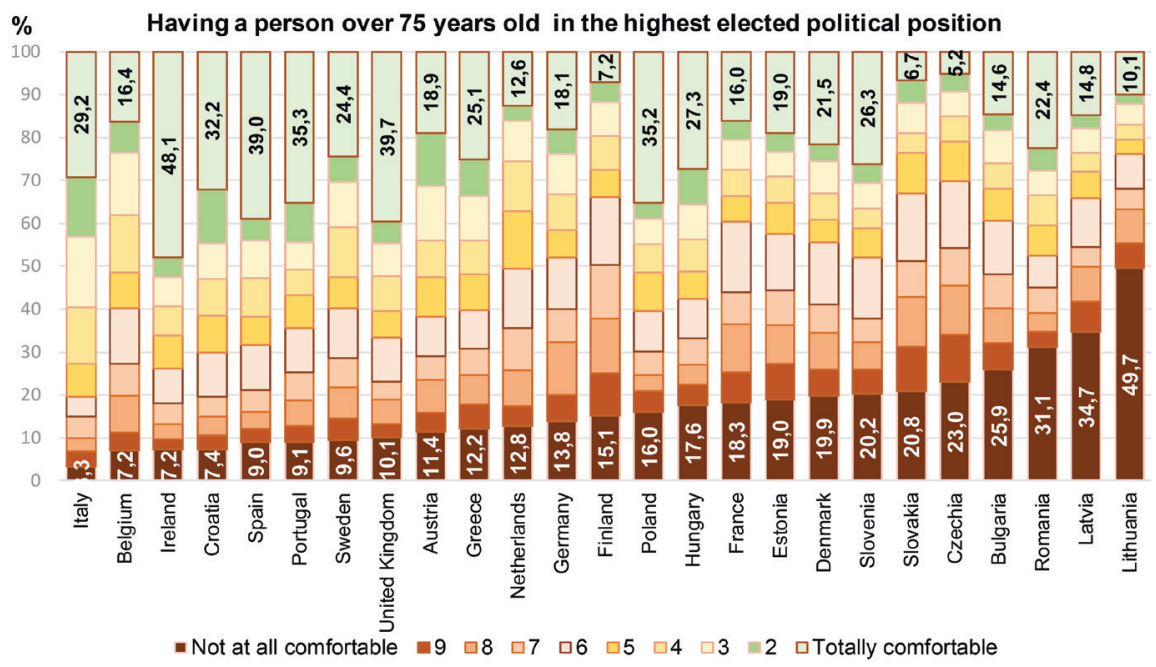

Figure 5. Ageist prejudice against old aged high officials Sorted according to Not at all comfortable N=22 728

Question: Using a scale from 1 to 10, please tell me how you would feel about having a person over 75 years old in the highest elected political position?

Coding: scale from $10=$ not at all comfortable to $1=$ totally comfortable

Source: Special Eurobarometer 437

related to ageism, a more sophisticated analytical approach based on multilevel modelling and micro-, macro-level selected explanatory factors has been applied in the next section.

\section{Ageism in EU: Multilevel modelling}

This section addresses individual and contextual perspectives by means of two-level modelling (level 1 = respondent characteristics, level 2 = country background). This integrated analysis enables to show how individual- (micro) level variables and macro- (country) level indicators impact age discrimination, taking into account personal and regional contexts.

Two key questions are addressed:

- What personal (individual-level) and socio-economic (country-level) characteristics predict people's attitudes towards the elderly?

- Are country differences of macro-level indicators relevant for understanding ageist opinions?

a) Perceived discrimination on the basis of being over 55 years old

Table 1 presents the results of five options of the multi-level regression model 1 (means-only; macro-level predictors; micro-level variables; both macro and micro indicators; and final model of only significant predictors). The outcome variable predicts the perception of discrimination due to being over 55 years old on a scale from $1=$ non-existent to $5=$ very widespread. The Intercept-only Model (unconditional model) shows that the mean discrimination score (intercept) is 3.2602 (it is the mean of country-specific means of discrimination scores, not the simple mean of scores reported by all respondents in the study). The intraclass 
correlation coefficient (ICC) tells us that about $5.7 \%$ of the total variation in perceived discrimination against people of 55+ years can be accounted for by the respondent's country of origin. In the model containing only macro-level predictors, just the Human Development Index (HDI) is statistically significant, meaning that for every one unit increase of HDI in a country, there is a -0.1970 decrease in the discrimination score (lower discrimination is coded with lower value). When micro-level predictors are included, the AIC (Akaike Information Criterion) decreases further (showing thus a more notable improvement of the model) and it suggests an essential relevance of personal characteristics for explaining of perceived discrimination against people of 55+ years old. The lowest value of AIC (71 822) favours the last model of relevant predictors. However, regression models with macro-level predictors only, micro- and macro- predictors, or relevant predictors show almost the same coefficients for micro-level indicators, thus confirming the stability of the personal markers.

Table 1. Random intercept model predicting discrimination based on being over 55 years old (Model 1).

\begin{tabular}{|c|c|c|c|c|c|}
\hline & $\begin{array}{l}\text { Unconditional } \\
\text { model }\end{array}$ & $\begin{array}{c}\text { Model with } \\
\text { macro-level } \\
\text { predictors }\end{array}$ & $\begin{array}{l}\text { Model with } \\
\text { micro-level } \\
\text { predictors }\end{array}$ & $\begin{array}{l}\text { Model with all } \\
\text { predictors }\end{array}$ & $\begin{array}{l}\text { Model with all } \\
\text { relevant predic- } \\
\text { tors at } \mathrm{p}<0.05\end{array}$ \\
\hline Intercept & 3.2602 & 3.2604 & 2.8217 & 2.8224 & 2.8223 \\
\hline \multicolumn{6}{|l|}{ Micro-level predictors } \\
\hline \multicolumn{6}{|l|}{ Gender } \\
\hline Man (ref) & & & 0 & 0 & 0 \\
\hline Woman & & & 0.139 & 0.1389 & 0.1388 \\
\hline \multicolumn{6}{|l|}{ Age } \\
\hline $15-24$ (ref) & & & 0 & 0 & 0 \\
\hline $25-34$ & & & 0.1996 & 0.2003 & 0.2002 \\
\hline $35-44$ & & & 0.2366 & 0.2375 & 0.2374 \\
\hline $45-54$ & & & 0.2885 & 0.2897 & 0.2896 \\
\hline $55-64$ & & & 0.3107 & 0.312 & 0.3119 \\
\hline 65-74 & & & 0.2328 & 0.2344 & 0.2343 \\
\hline $75+$ & & & 0.1665 & 0.1683 & 0.1682 \\
\hline \multicolumn{6}{|l|}{ Partnership status } \\
\hline $\begin{array}{l}\text { (Re-)Marries/single with } \\
\text { partner (ref) }\end{array}$ & & & 0 & 0 & 0 \\
\hline Divorced or separated & & & 0.0861 & 0.087 & 0.0869 \\
\hline Widowed & & & 0.0083 & 0.0081 & 0.008 \\
\hline Single & & & 0.0025 & 0.0035 & 0.0035 \\
\hline \multicolumn{6}{|l|}{ Social class } \\
\hline Middle class (ref) & & & 0 & 0 & 0 \\
\hline Working class & & & 0.0457 & 0.0454 & 0.0455 \\
\hline Lower middle class & & & 0.0217 & 0.0218 & 0.0219 \\
\hline Upper middle class & & & 0.0741 & 0.0749 & 0.0747 \\
\hline Higher class & & & -0.0533 & -0.0531 & -0.0534 \\
\hline \multicolumn{6}{|l|}{ Life satisfaction } \\
\hline Very satisfied (ref) & & & 0 & 0 & 0 \\
\hline Fairly satisfied & & & 0.1066 & 0.1046 & 0.1048 \\
\hline Not very satisfied & & & 0.199 & 0.1955 & 0.1958 \\
\hline Not at all satisfied & & & 0.3928 & 0.3889 & 0.3893 \\
\hline \multicolumn{6}{|l|}{ Macro-level predictors } \\
\hline Life expectancy at 55 & & 0.0666 & & 0.0543 & \\
\hline
\end{tabular}




\begin{tabular}{|c|c|c|c|c|c|}
\hline & $\begin{array}{l}\text { Unconditional } \\
\text { model }\end{array}$ & $\begin{array}{c}\text { Model with } \\
\text { macro-level } \\
\text { predictors }\end{array}$ & $\begin{array}{c}\text { Model with } \\
\text { micro-level } \\
\text { predictors }\end{array}$ & $\begin{array}{l}\text { Model with all } \\
\text { predictors }\end{array}$ & $\begin{array}{l}\text { Model with all } \\
\text { relevant predic- } \\
\text { tors at } \mathrm{p}<0.05\end{array}$ \\
\hline Perceived start of old age & & -0.0173 & & -0.0178 & \\
\hline $\begin{array}{l}\text { Human development } \\
\text { index }\end{array}$ & & -0.197 & & -0.1556 & -0.1187 \\
\hline $\begin{array}{l}\text { ICC (intraclass correla- } \\
\text { tion coefficient) }\end{array}$ & 0.057 & 0.04 & 0.051 & 0.04 & 0.04 \\
\hline $\begin{array}{l}\text { AIC (Akaike Information } \\
\text { Criterion) }\end{array}$ & 72221 & 72218 & 71826 & 71825 & 71822 \\
\hline $\begin{array}{l}N \text { (number of respon- } \\
\text { dents in } 25 \text { countries) }\end{array}$ & 23872 & 23872 & 23872 & 23872 & 23872 \\
\hline
\end{tabular}

The last option with statistically significant coefficients shows that women perceive higher age discrimination (0.1388) compared to men (0). The marginalization of women was observed throughout history when they occupied a lower social status and were disadvantaged at labour markets. Even today, after adjusting for the remaining variables in the model, this discrimination is significant. We also talk about gendered ageism, which refers to the difference in stereotyping and discriminating older men versus older women, and which leads to faster deterioration of older women's status compared to men (Krekula et al. 2018). This fact is explained by persisting patriarchal norms. In terms of age, the increase in perceived ageism is most noticeable for ages 45-64, i.e. pre-retirement age. People are more likely to perceive discrimination in a situation that is characterized by negative stereotypes expressing lower productivity in the work of older adults (Voss et al. 2018).

The Modernization Theory explains the loss of social status experienced by older workers in modern times due to a devaluation of their performance (Ayalon and Tesch-Römer 2018). However, from age 65 the feeling of perceived discrimination decreases, which is likely related to a more secure situation for pensioners (having a steady income - pension), no longer being forced to compete for subsistence at the labour market and being responsible only for themselves (not for their minor children). In addition, old people can also enjoy positive stereotypes, e.g. when being considered as warm and emphatic by younger people (Stereotype Content Model). Divorced or separated people perceive to be more discriminated $(0.0869)$ than those living in a couple (0). This outcome could be related to possibly worse health of divorced persons (selection effect), as reported in many studies (Hank and Steinbach 2018). Consequently, worse health combined with the new stress of a failing partnership can produce the feeling of marginalisation and discrimination.

Belonging to upper middle class (0.0747) or working class (0.0455) compared to middle class (0) also generates a sentiment of perceived discrimination. Social or socioeconomic status affects overall human functioning, including physical and mental health. Those with lower levels of socioeconomic status or social class are more likely to experience worse health and have a greater risk of depression. Belonging to a lower social class also means benefitting less from educational or employment opportunities that would eventually increase social mobility, which in turn could improve personal situation (Manstead 2018). People in the upper middle-class may perceive themselves as an in-group between middle and higher class. When social stratification starts to become unstable, members of an in-group may experience 'fear of falling', the fear of losing their relative advantages. This fear may also explain the increased perceived discrimination in the upper middle class compared to the middle class. In summary, during periods of detrimental conditions, people may experience increased anxiety about losing their privileges and are consequently more likely to perceive discrimination (Caricati 2018). Life satisfaction has an important predictive power on perceived 
discrimination; hence, it can be considered a general proxy for subjective well-being and is associated with the feeling of perceived discrimination. People who are not satisfied by life may become more easily marginalized and may think that discrimination against those aged 55+ is more widespread (0.3893) compared to those who enjoy very a satisfied life (0). The Human Development Index has been identified as the only statistically significant contextual variable for explaining the level of perceived discrimination of age 55+. A higher Human Development Index, as a measure of a societal advancement, decreases the feeling of perceived discrimination against 55+ year olds. Thus, societal modernisation (a sociological construct referring to profound economic, social and cultural transition from 'pre-modern', 'traditional' societies to 'modern' societies), implied by the Human Development Index, has an impact on the reduction of ageism (Swift et al. 2018).

When looking at country differences (although weak; ICC $=4 \%$; last model option) as shown in Figure 6 (model 1, level 2, option: all relevant predictors), we cannot observe the traditionally expected gradient from 'West' to 'East'. The estimated deviations from the intercept show that the lowest perceived discrimination against older people is observed in Poland, while France appears to be the most ageist country for people aged 55 and over. Czechia, which shared a border, as well as a communist past with Poland, ranks in the second highest ageist position and thus joins the club of negative stereotypes together with France, United Kingdom, and Netherlands. After Poland, the second lowest ranking country in terms of age discrimination is Denmark. The previous Special Eurobarometer 296 on Discrimination published in 2008, showed similar results for Hungary and Czechia ranked at the top of perceived discrimination against people 55+ years old. France, the United Kingdom and the Netherlands were above EU27 average, while Ireland and Denmark showed the lowest perceived discrimination. The position of Poland was below EU27 average. These findings suggest that it is not an easy undertaking to reveal straightforward associations between perceived ageism against old people and geography, religion, culture, or level of economic development. Differing results were observed when examining country differentials of experienced discrimination amongst Europeans aged 62 and over, based on data

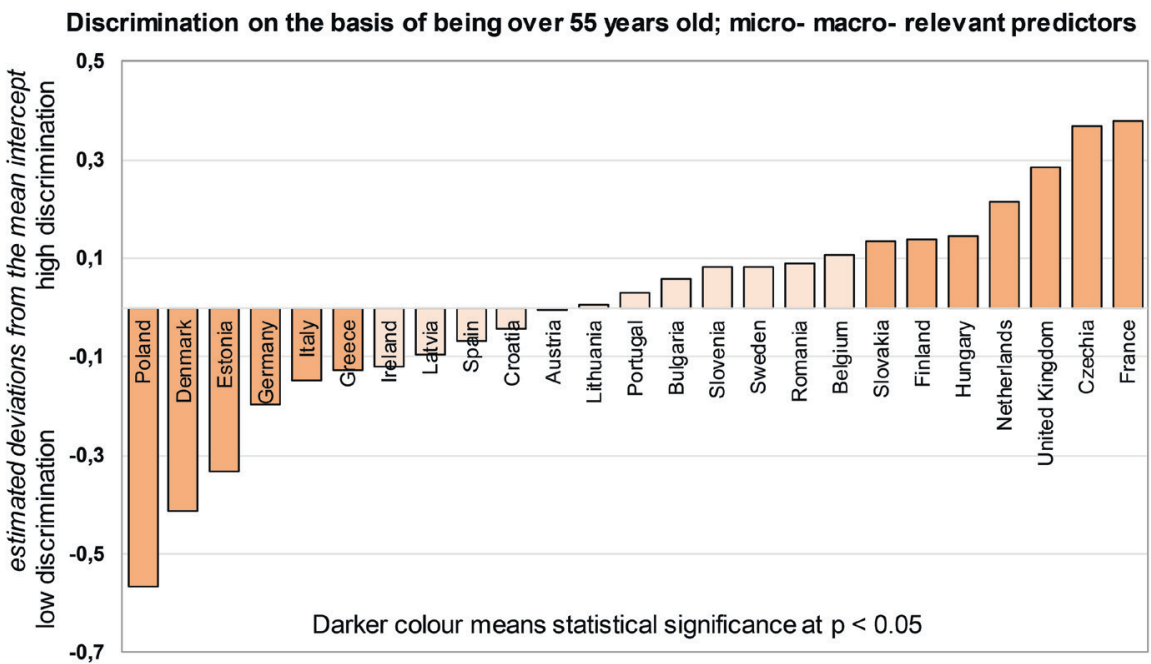

Figure 6. Country ranking according to perceived discrimination against people 55+ years old. Source : author's calculations 
from the European Social Survey 2008 (van den Heuvel and van Santvoort 2011). Excessive experienced discrimination was found in Czechia, Slovakia, Bulgaria and Greece, but not in France or the United Kingdom. The lowest level of experienced age discrimination was observed in Sweden, Denmark and Norway, while Poland had an average score in that respect. Because of our contradictory results regarding country differences in perceived ageist attitudes, we consider that finding a full set of explicative causal factors for perceived ageism is beyond the scope of this contribution. Indeed, it would be necessary to study the contexts in greater detail in each individual country.

b) Potential discrimination of people over 55 years old during economic crisis

Competition over scarce resources can lead to negative intergroup attitudes or hostility. During hard times, as in periods of economic crisis, the idea to exclude people over 55 years of age from recovery initiatives, like protecting or retraining unemployed, can be appealing. Intergroup Threat Theory or Intergenerational Conflict Theory are grounded on expectations that participation in activities by older people should be regulated or better, reserved for younger people, because older generations' more limited consumption. Model 2 addresses this issue (Table 2).

Table 2. Random intercept model predicting a discrimination of people aged 55 and over during an economic crisis (Model 2).

\begin{tabular}{|c|c|c|c|c|c|}
\hline & $\begin{array}{c}\text { Unconditional } \\
\text { model }\end{array}$ & $\begin{array}{c}\text { Model with } \\
\text { macro-level } \\
\text { predictors }\end{array}$ & $\begin{array}{c}\text { Model with } \\
\text { micro-level } \\
\text { predictors }\end{array}$ & $\begin{array}{c}\text { Model with } \\
\text { all predic- } \\
\text { tors }\end{array}$ & $\begin{array}{c}\text { Model with all } \\
\text { relevant predic- } \\
\text { tors at } \mathrm{p}<0.05\end{array}$ \\
\hline Intercept & 2.5561 & 2.5562 & 2.431 & 2.4317 & 2.4315 \\
\hline \multicolumn{6}{|l|}{ Micro-level predictors } \\
\hline \multicolumn{6}{|l|}{ Gender } \\
\hline Man (ref) & & & 0 & 0 & 0 \\
\hline Woman & & & 0.0776 & 0.0777 & 0.0777 \\
\hline \multicolumn{6}{|l|}{ Age } \\
\hline $15-24$ (ref) & & & 0 & 0 & 0 \\
\hline $25-34$ & & & 0.0254 & 0.025 & 0.0253 \\
\hline $35-44$ & & & -0.0055 & -0.0061 & -0.0057 \\
\hline $45-54$ & & & 0.0182 & 0.0175 & 0.018 \\
\hline $55-64$ & & & 0.0686 & 0.0678 & 0.0685 \\
\hline $65-74$ & & & 0.046 & 0.0449 & 0.0456 \\
\hline $75+$ & & & 0.0526 & 0.0516 & 0.0522 \\
\hline \multicolumn{6}{|l|}{ Partnership status } \\
\hline (Re-)Marries/single with partner (ref) & & & 0 & 0 & 0 \\
\hline Divorced or separated & & & -0.0035 & -0.0028 & -0.0029 \\
\hline Widowed & & & -0.0655 & -0.0646 & -0.0647 \\
\hline Single & & & 0.024 & 0.0237 & 0.0239 \\
\hline \multicolumn{6}{|l|}{ Social class } \\
\hline Middle class (ref) & & & 0 & 0 & 0 \\
\hline Working class & & & 0.0479 & 0.0481 & 0.0477 \\
\hline Lower middle class & & & 0.0394 & 0.0398 & 0.0392 \\
\hline Upper middle class & & & -0.0153 & -0.0158 & -0.0151 \\
\hline Higher class & & & -0.1475 & -0.1468 & -0.1459 \\
\hline \multicolumn{6}{|l|}{ Life satisfaction } \\
\hline Very satisfied (ref) & & & 0 & 0 & 0 \\
\hline Fairly satisfied & & & 0.0288 & 0.0287 & 0.0284 \\
\hline
\end{tabular}




\begin{tabular}{lccccc}
\hline & $\begin{array}{c}\text { Unconditional } \\
\text { model }\end{array}$ & $\begin{array}{c}\text { Model with } \\
\text { macro-level } \\
\text { predictors }\end{array}$ & $\begin{array}{c}\text { Model with } \\
\text { micro-level } \\
\text { predictors }\end{array}$ & $\begin{array}{c}\text { Model with } \\
\text { all predic- } \\
\text { tors }\end{array}$ & $\begin{array}{c}\text { Model with all } \\
\text { relevant predic- } \\
\text { tors at p<0.05 }\end{array}$ \\
\hline Not very satisfied & & & 0.0896 & 0.089 & 0.0889 \\
Not at all satisfied & & 0.1737 & 0.173 & 0.1728 \\
Macro-level predictors & & & & \\
Life expectancy at 55 & & 0.2044 & & 0.1913 & 0.2573 \\
Perceived start of old age & & 0.0707 & & 0.0741 & \\
Human development index & & -0.1997 & & -0.1752 & -0.2011 \\
ICC (intraclass correlation coefficient) & 0.053 & 0.024 & 0.051 & 0.023 & 0.027 \\
AIC (Akaike Information Criterion) & 61181 & 61167 & 61103 & 61089 & 61090 \\
N (number of respondents in 25 countries) & 22421 & 22421 & 22421 & 22421 & 22421 \\
\hline
\end{tabular}

Question: Do you think that measures to fight the economic crisis and policies to promote recovery are excluding people over 55 years old? $1=$ No, definitely not; $2=$ No, not really; $3=$ Yes, to some extent; $4=$ Yes, definitely.

Note: statistically significant coefficients at $\mathrm{p}<0.05$ are in bold; at $\mathrm{p}<0.1$ are in italics Source: author's calculations. Data: Eurobarometer 437

The dependent variable is based on the question whether measures or policies to tackle the economic crisis and to promote recovery should exclude people over 55 years of age. Intercepts (mean scores of discrimination) have similar values for each model option (null model; model with macro- or micro-level predictors; with all predictors; and relevant predictors). The model with macro-level predictors only (Table 2) shows that societies where life expectancy at age of 55 is higher tend to adopt more restrictive measures against people aged 55 and over. However, when looking at Human Development Index (HDI), a higher coefficient is correlated with a lower discrimination score, as found in the previous model. This result is rather unexpected and peculiar, because when considering only the coefficient of correlation between HDI and $e_{55}$ for countries in the study we find a value of 0.796 , i.e. a positive relationship between 'prosperity' and longevity. However, this correlation is driven by 'Eastern' countries, where this correlation coefficient ( $e_{55}$ versus HDI) is 0.880 (higher HDI means longer $\mathrm{e}_{55}$ ). On the contrary, in the 'West' (defined as the group without post-socialist countries) this coefficient amounts to -0.311 . This negative correlation can be explained by higher longevity but lower HDI in Southern Europe (primarily Italy and Spain), while Denmark or the Netherlands with high HDI experience shorter $\mathrm{e}_{55}$ by Western standards. This situation is also reproduced when correlating each indicator separately (HDI, $\mathrm{e}_{55}$ ) with the percentage of people expressing ageist attitudes during an economic crisis (Figure 7). Looking at the slope of the regression line, from the percentage of respondents agreeing with ageist measures and $e_{55}$ we see a positive slope (primarily Southern countries more affected by unemployment), while the slope of the regression line for the percentage of those disagreeing with ageist measures and HDI is negative, primarily in Western countries (Denmark, Germany, Netherlands). People in 'Eastern' Europe were more cautious (low correlations) to approve such restrictive initiatives. These results demonstrate the complexity and difficulty of selecting suitable macro-level predictors, which in some cases can be controversial.

Table 2 (option with relevant predictors) shows that women are more affected by potential discrimination (0.0777) during perturbed times than men. Regarding age, only people of pre-retirement age (55-64) are likely to be affected by restrictive measures, while regression coefficients for other age groups are not statistically significant. The age profile of perceived ageism in this model (Table 2) is different from the previous one (Table 1). Model 2 shows 


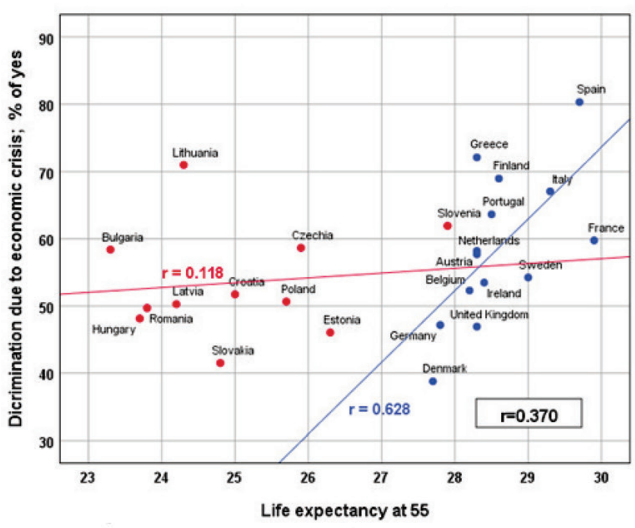

a)

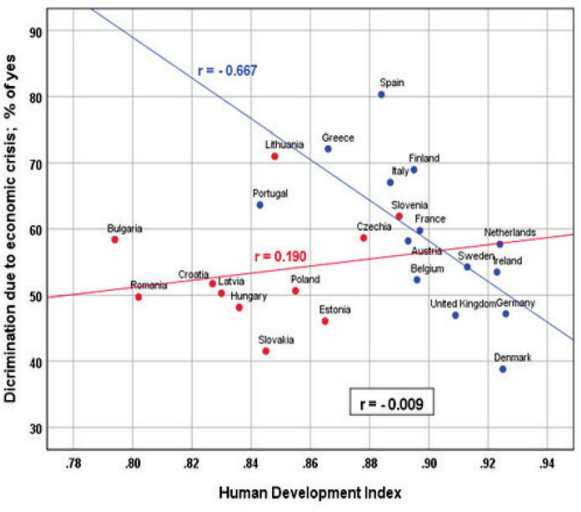

b)

Figure 7. Scatter plot of discrimination of people 55+ old during economic crises versus a) Life expectancy at 55 and b) Human Development Index

Note: Discrimination is defined as the percentage of answers $3=y e s$ to some extent $+4=y e s$ definitely

two vulnerable age groups affected by potential ageist actions, i.e. 25-34 (though insignificant) and 55-64. Older workers tend to be overrepresented in public administration, health and education sectors and may therefore be more exposed to the consequences of current and future public spending cuts (Eurofond 2012). Unlike in the previous model, widowed people are more at risk of becoming victims of restrictive measures. Additionally, people from lower classes are more at risk of unemployment and their families are more affected during an economic recession due to lower savings. It seems no surprise that people from lower social classes tend to agree with measures against people aged 55 and over. A similar gradient is observed regarding life satisfaction; the less people are satisfied with life, the more they are in favour of socioeconomic restrictions related to seniors.

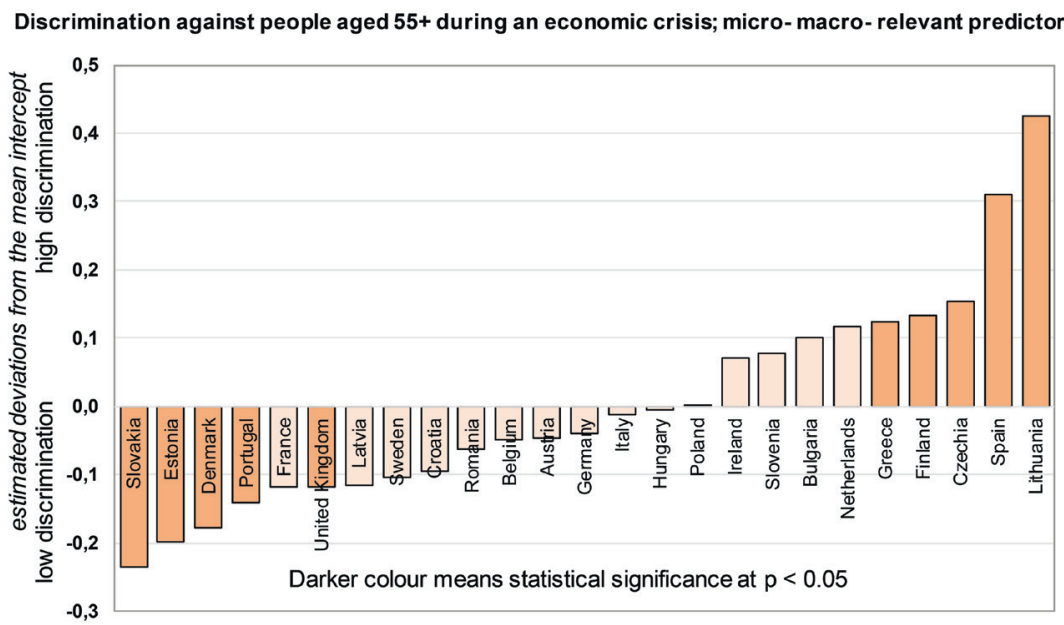

Figure 8. Country ranking according to discrimination against people 55+ year old during an economic crisis. Source : author's calculations 
Figure 8 shows country ranks according to people's statements on restrictive measures against $55+$ year olds during an economic crisis. Discriminatory views are found in Lithuania, Spain, Czechia and Finland, while in Slovakia, Estonia, and Denmark people are not favourable towards adopting special measures aimed to exclude older persons during hard economic times.

c) Age discrimination in elections for a high political position

Understanding age-related changes in cognition is particularly important when considering positions with high responsibility. There is evidence that alternations in the brain structure and function impact cognitive functions as age advances (Glisky 2007). The most important changes in cognition occur in the performance of tasks that require to process information quickly and to make appropriate decisions consequently. High-performance, executive, cognitive function is very important for novel tasks (Murman 2015). The fundamental source of age-related deficits is related to working memory. Working memory is important for reasoning, guiding decision-making and behaviour. It allows for the manipulation of stored information. Deficits in tasks demanding high and divided attention appear with increasing age, meaning that older adults are often impaired regarding working memory (Glisky 2007).

People have different roles and power in society. Positive personal relationships across intergroups are likely to produce less stereotypes of the outgroup as a whole. However, people feel rather more favourable towards their own age groups. Table 3 shows, among other things, the extent to which people aged 75 and over are perceived as acceptable in the hig-

Table 3. Random intercept model predicting ageist prejudice against old aged high officials (Model 3).

\begin{tabular}{|c|c|c|c|c|c|}
\hline & $\begin{array}{c}\text { Unconditional } \\
\text { model }\end{array}$ & $\begin{array}{c}\text { Model with } \\
\text { macro-level } \\
\text { predictors }\end{array}$ & $\begin{array}{c}\text { Model with } \\
\text { micro-level } \\
\text { predictors }\end{array}$ & $\begin{array}{l}\text { Model with all } \\
\text { predictors }\end{array}$ & $\begin{array}{c}\text { Model with all } \\
\text { relevant predictors } \\
\text { at } \mathrm{p}<0.05\end{array}$ \\
\hline Intercept & 5.2153 & 5.2152 & 4.6079 & 4.6075 & 4.6086 \\
\hline \multicolumn{6}{|l|}{ Micro-level predictors } \\
\hline \multicolumn{6}{|l|}{ Gender } \\
\hline Man (ref) & & & 0 & 0 & 0 \\
\hline Woman & & & 0.1164 & 0.1162 & 0.1161 \\
\hline \multicolumn{6}{|l|}{ Age } \\
\hline $15-24$ (ref) & & & 0 & 0 & 0 \\
\hline $25-34$ & & & 0.0707 & 0.071 & 0.0718 \\
\hline $35-44$ & & & 0.1395 & 0.14 & 0.141 \\
\hline $45-54$ & & & 0.3972 & 0.398 & 0.3992 \\
\hline $55-64$ & & & 0.8051 & 0.8059 & 0.8073 \\
\hline $65-74$ & & & 0.6707 & 0.6721 & 0.6736 \\
\hline $75+$ & & & 0.504 & 0.5063 & 0.5078 \\
\hline \multicolumn{6}{|l|}{ Parnership status } \\
\hline $\begin{array}{l}\text { (Re-)Marries/single } \\
\text { with partner (ref) }\end{array}$ & & & 0 & 0 & 0 \\
\hline Divorced or separated & & & 0.2298 & 0.2308 & 0.2315 \\
\hline Widowed & & & -0.0343 & -0.0353 & -0.035 \\
\hline Single & & & 0.0323 & 0.0334 & 0.0342 \\
\hline \multicolumn{6}{|l|}{ Social class } \\
\hline Middle class (ref) & & & 0 & 0 & 0 \\
\hline Working class & & & 0.2463 & 0.2459 & 0.2453 \\
\hline Lower middle class & & & 0.1265 & 0.1267 & 0.1264 \\
\hline Upper middle class & & & -0.1727 & -0.1723 & -0.1714 \\
\hline Higher class & & & 0.2743 & 0.2723 & 0.2735 \\
\hline
\end{tabular}




\begin{tabular}{|c|c|c|c|c|c|}
\hline & $\begin{array}{l}\text { Unconditional } \\
\text { model }\end{array}$ & $\begin{array}{c}\text { Model with } \\
\text { macro-level } \\
\text { predictors }\end{array}$ & $\begin{array}{l}\text { Model with } \\
\text { micro-level } \\
\text { predictors }\end{array}$ & $\begin{array}{l}\text { Model with all } \\
\text { predictors }\end{array}$ & $\begin{array}{c}\text { Model with all } \\
\text { relevant predictors } \\
\text { at } \mathrm{p}<0.05\end{array}$ \\
\hline \multicolumn{6}{|l|}{ Life satisfaction } \\
\hline Very satisfied (ref) & & & 0 & 0 & 0 \\
\hline Fairly satisfied & & & -0.0052 & -0.0056 & -0.0079 \\
\hline \multirow[t]{2}{*}{$\mathrm{N}$} & & & 0.1609 & 0.1594 & 0.1558 \\
\hline & & & 0.2956 & 0.2944 & 0.2902 \\
\hline \multicolumn{6}{|l|}{ Macro-level predictors } \\
\hline Life expectancy at 55 & & -0.9759 & & -0.9787 & -0.5306 \\
\hline $\begin{array}{l}\text { Perceived start of } \\
\text { old age }\end{array}$ & & 0.1378 & & 0.1321 & \\
\hline $\begin{array}{l}\text { Human development } \\
\text { index }\end{array}$ & & 0.4331 & & 0.4617 & \\
\hline $\begin{array}{l}\text { ICC (intraclass correla- } \\
\text { tion coefficient) }\end{array}$ & 0.104 & 0.074 & 0.103 & 0.073 & 0.08 \\
\hline $\begin{array}{l}\text { AIC (Akaike Informa- } \\
\text { tion Criterion) }\end{array}$ & 115969 & 115965 & 115706 & 115703 & 115701 \\
\hline $\begin{array}{l}\mathrm{N} \text { (number of respon- } \\
\text { dents in } 25 \text { countries) }\end{array}$ & 22728 & 22728 & 22728 & 22728 & 22728 \\
\hline
\end{tabular}

Question: Using a scale from 1 to 10. please tell me how you would feel about having a person over 75 years old in the highest elected political position? From $10=$ not at all comfortable to $1=$ totally comfortable.

Note: statistically significant coefficients at $\mathrm{p}<0.05$ are in bold; at $\mathrm{p}<0.1$ are in italics

Source: Author's calculations; Data: Eurobarometer 437

hest political position by different age groups. It is a bit surprising that the older the respondents, the less willing they are to vote for a politician aged $75+$.

The highest coefficients of disagreement are found in ages 55-64 (0.8073) and 65-74 (0.6736). For young people, this issue seems not important. The results contradict the Social

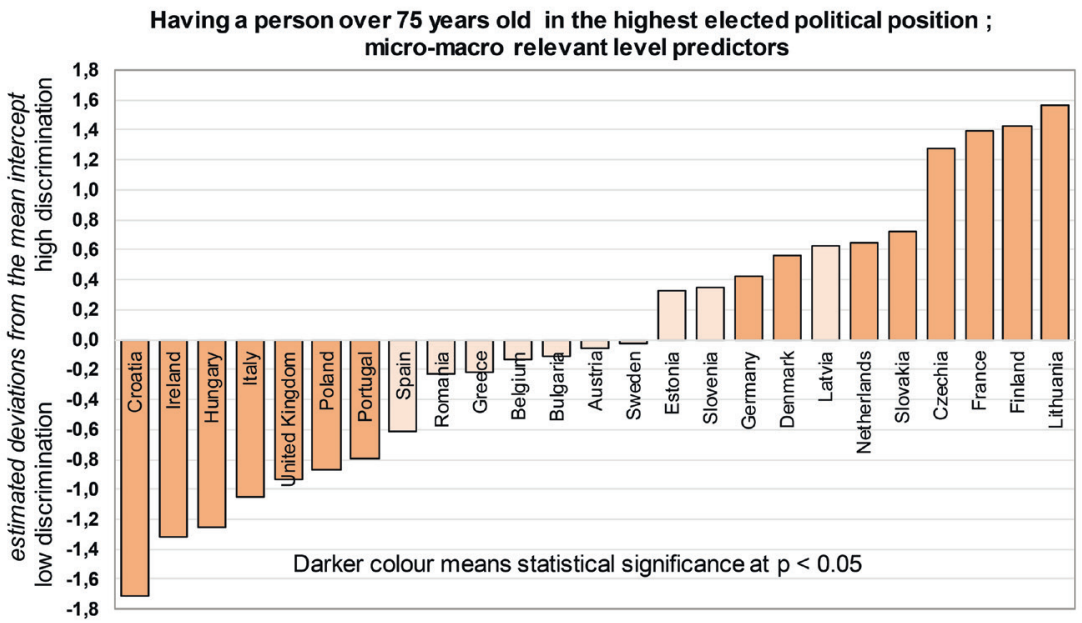

Figure 9. Country ranking according to discrimination against people $75+$ years old as the highest political official. Source: author's calculations 
Identity Theory stating that people identify with an own group and are more likely to defend its status. Women are less comfortable (0.1161) with an old political official than men (Table 3 , option all relevant predictors). Divorced, lower class (working and lower middle class) and those not at all or not very satisfied are not very comfortable with having a person over 75 years of age in the highest elected political position. The model also shows that, populations with shorter life expectancy at age 55 are more likely to be uncomfortable with an old high official (-0.5306). This result could be linked to the fact that populations with shorter $\mathrm{e}_{55}$ report an even shorter period spent in good health (Robine and Cambois 2013), hence they may have less confidence in the health performance of older aged politicians.

Figure 9 shows larger variability among countries. Political officials aged over 75 are not accepted with much enthusiasm in Lithuania, Finland, France, Czechia, Slovakia, and the Netherlands. On the other hand, it seems that for Croatia, Ireland, Hungary, Italy, the United Kingdom, Poland and Portugal an old political representative is acceptable. The ICC of $8 \%$ confirms a more substantial variation between countries on this topic compared to the previous two models.

\section{Conclusions}

Population ageing, as a global phenomenon of the $21^{\text {st }}$ century, will affect everybody. Looking presently at the 25 analysed countries, the proportion of seniors primarily puts former socialist countries (younger population age structure) and Southern Europe, where populations are much older, at opposite ends. However, the picture is somewhat ambiguous as Latvia and Bulgaria, due to very low fertility levels, already belong to 'old populations'. Both are likely frontrunners for the remaining post-socialist countries, as their populations are predicted to age fast because of the recent profound fertility decline.

Within the context of ongoing and future uneven global population ageing, old age discrimination - ageism can, in a number of ways, impact social cohesion, health and wellbeing of European societies. However, the research of perceived discrimination based on three different domains has shown that the traditional East-West gap does not appear in this context. The picture is neither clear in the 'East' nor in the 'West'. Czechia is the only Eastern country showing consistent results of ingrained discriminatory attitudes towards the elderly population across all three examined domains of discrimination. Polish citizens on the other hand, perceive much less frequent discrimination in general and consider it acceptable to elect an old person into high political position. Unlike Poland, Slovakia does not support discriminatory measures against the elderly during the times of economic crisis. In the 'West', the Netherlands and Finland show discrimination against old age in all three domains, while in France ageism is reported for the first question on perceived discrimination in general and when electing a person aged 75 and over into high political office.

The regression analysis has shown that the effects of personal characteristics are much significant than country contexts in perceived ageism. Ageism perceived by women appears stronger when compared to men across all three models. Older chronological age is expected to be associated with more intense perception of ageism. However, it is mostly notable for pre-retirement ages related to the question about general ageist perception; this age specificity is intensified in times of economic crisis. Individuals belonging to higher social groups and those in partnerships usually enjoy better life satisfaction, which the results showing a reduced disposition or sensitivity towards ageism confirm. 
The Eurobarometer 2015 data on perceived ageism provide a framework for understanding people's attitudes across three domains (in general, during hard times, and in politics) according to individual characteristics as well as country contexts. The impact of gender, age or wellbeing show to some extent similar directions already presented by ESS studies. However, the East-West gradient, frequently reported, is questioned when considering our findings, as the geographical picture is rather puzzling.

The studies of this type, combining micro- and macro-level indicators, are important and of enduring importance, because they provide not only information about people's potential isolation and exclusion at old age, but can help in guiding policies on issues of age equality, specifically for each country. These findings can indicate opportunities for changing negative perceptions or stigmas of ageing that will affect everyone. Future research could further explore the differences between countries on the opposite ends of the geographical ageist spectrum (Czechia versus Poland or Finland versus Denmark), however this is beyond scope of this contribution.

\section{Acknowledgements}

The study was supported by the Czech Science Foundation, project GA ČR No.18-12166S

\section{References}

Abrams D, Vauclair ChM, Swift H (2011) Predictors of attitudes to age across Europe. Department for Work and pensions, Research Report No 735, 90p.

Ageing Demographic Data Sheet (2018) IIASA: Laxenburg, Austria http://www.iiasa.ac.at/web/home/ research/researchPrograms/WorldPopulation/PublicationsMediaCoverage/ModelsData/AgingDemDataSheet2018_web.pdf

Ayalon L, Tesch-Römer C (2018) Introduction to the Section: Ageism-Concept and Origins. In: Ayalon L, Tesch-Römer C (Eds) Contemporary Perspectives on Ageism. International Perspectives on Aging, vol 19. Springer https://link.springer.com/content/pdf/10.1007\%2F978-3-319-73820-8_1.pdf

Bell BA, Ene M, Smiley W, Schoeneberger JA (2013) A Multilevel Model Primer Using SAS ${ }^{\oplus}$ PROC MIXED. SAS Global Forum 2013, Paper 433-2013, 19 p. https://support.sas.com/resources/papers/ proceedings13/433-2013.pdf

Butler RN (1969) Ageism: Another form of bigotry. The Gerontologist, 9(4): 243-246.

Butler RN (1980) Ageism: A foreword. Journal of Social Issues, 36(2): 8-11

Caricati L (2018) Considering intermediate - status groups in intergroup hierarchies: A theory of triadic social stratification. Journal of Theoretical Social Psychology, 2: 58-66 https://onlinelibrary. wiley.com/doi/full/10.1002/jts5.19

Cuddy A, Norton M, Fiske S (2005) This old stereotype: The pervasiveness and persistence of the elderly stereotype. Journal of Social Issues, 61(2): 267-285.

Dannefer D, Shura R (2009) Experience, Social Structure and Later Life: Meaning and Old Age in an Aging Society. In: Uhlenberg P (Eds) International Handbook of Population Aging. International Handbooks of Population, vol 1. Springer, Dordrecht, 747-755.

Eurofond (2012) Employment trends and policies for older workers in the recession. 12p. https:// www.eurofound.europa.eu/publications/report/2012/labour-market-social-policies/employmenttrends-and-policies-for-older-workers-in-the-recession 
European Social Survey (2008) Ageism. https://www.europeansocialsurvey.org/data/themes.htm$1 ? \mathrm{t}=$ ageism

Experiences and Expressions of Ageism: Module template with background information, survey questions. 27p. https://www.europeansocialsurvey.org/docs/round4/questionnaire/ESS4_final_ageism_module_template.pdf

Fiske ST, Cuddy AJC, Glick P, Jun Xu (2002) A model of (Often Mixed) Stereotype Content: Competence and Warmth Respectively Follow from Perceived Status and Competition. Journal of Personality and Social Psychology, 82(6): 878-902. https://cos.gatech.edu/facultyres/Diversity_Studies/ Fiske_StereotypeContent.pdf

Ghishlandi S, Sanderson WC, Scherbov S (2018) A Simple Measure of Human Development: the Human Life Indicator Population and Development Review, 45(1): 219-233. http://www.iiasa.ac.at/ web/home/research/researchPrograms/WorldPopulation/Reaging/HLI.html

Glisky EL (2007) Changes in Cognitive Function in Human Aging. In: Riddle DR (Eds) Brain Aging: Models, Methods, and Mechanisms. Boca Raton (FL): CRC Press/Taylor \& Francis. https://www. ncbi.nlm.nih.gov/books/NBK3885/\#ch1.rl1

Green MJ, Benzeval M (2010) Ageing, social class and common mental disorders: longitudinal evidence from three cohorts in the West of Scotland. Psychological medicine, 41(3): 565-574.

Hagestad GO, Uhlenberg P (2006). Should We Be Concerned About Age Segregation? Research on Aging 28(6): 638-653. www.iiasa.ac.at/web/home/research/researchPrograms/WorldPopulation/ Reaging/HLI.html

Hank K, Steinbach A (2018) Families and Health: A Review. In: Doblhammer G, Gumà J (Eds) A Demographic Perspective on Gender, Family and Health in Europe. Springer, Cham https://link. springer.com/chapter/10.1007/978-3-319-72356-3_3\#citeas

Kim H, Kang H (2017) The influence of ageism on life satisfaction of older adults. Innovation in Aging, 1 (Suppl 1): 116-117.

Kotter-Grühn D (2015) Changing negative views of aging: Implications for intervention and translational research. Annual Review of Gerontology and Geriatrics, 35: 167-186.

Levy B (2009) Stereotype Embodiment: A Psychosocial Approach to Aging. Current Directions in Psychological Science, 18(6): 332-336. https://www.ncbi.nlm.nih.gov/pmc/articles/PMC2927354/ pdf/nihms155298.pdf

Krekula C, Nikander P, Wilińska M (2018) Multiple Marginalizations Based on Age: Gendered Ageism and Beyond. In: Ayalon L, Tesch-Römer C (Eds) Contemporary Perspectives on Ageism. International Perspectives on Aging, vol 19. Springer, Cham https://ink.springer.com/chapter/10.1007/978-3-319-73820-8_3\#citeas

Levy B (2003) Mind Matters: Cognitive and Physical Effects of Aging Self-Stereotypes, Series B, 58(4). https://academic.oup.com/psychsocgerontology/article/58/4/P203/523293

Livi-Bacci M (2001) A Concise History of World Population. Wiley-Blackwell; 3 edition, 286 p.

Löckenhoff CE, De Fruyt F, Terracciano A, et al. (2009) Perceptions of aging across 26 cultures and their culture-level associates. Psychol Aging. 24(4): 941-954. https://www.ncbi.nlm.nih.gov/pmc/ articles/PMC2933107/pdf/nihms-215302.pdf

Loos E, Ivan L (2018) Visual Ageism in the Media. In: Ayalon L, Tesch-Römer C (Eds) Contemporary Perspectives on Ageism. International Perspectives on Aging, vol 19. Springer, Cham. https://link. springer.com/chapter/10.1007/978-3-319-73820-8_11

Manstead ASR (2018) The psychology of social class: How socioeconomic status impacts thought, feelings, and behaviour. British Journal of Social Psychology (2018), 57: 267-291. 
Marques S, Swift HJ, Vauclair ChM, Lima ML, Bratt Ch, Abrams D (2015) 'Being old and ill' across different countries: Social status, age identification and older people’s subjective health, Psychology \& Health, 30(6): 699-714. https://www.tandfonline.com/doi/abs/10.1080/08870446.2014.938742

Meslé F, Vallin J (2000) Transition sanitaire: Tendances et perspectives. Médecine/science. 16(1): 11611171. http://www.ipubli.inserm.fr/bitstream/handle/10608/1549/2000_11_1161.pdf?sequence=6

Monnier A (2006) Démographie contemporaine de l'Europe. Armand Colin, 415p.

Mullan P (2002) The Imaginary Time Bomb: Why an Ageing Population is Not a Social Problem. I.B. Tauris; New edition, 239p.

Murman DL (2015) The Impact of Age on Cognition. Seminars in hearing, 36(3): 111-121. https:// www.ncbi.nlm.nih.gov/pmc/articles/PMC4906299/

Nelson T (2005) Ageism: Prejudice against our feared future self. Journal of Social Issues, 61(2): 207221.

North MS, Fiske T (2013) A Prescriptive, Intergenerational-Tension Ageism Scale: Succession, Identity, and Consumption (SIC). Psychol Assessment, 25(3): 706-713. https://www.ncbi.nlm.nih.gov/ pmc/articles/PMC3912745/pdf/nihms-548084.pdf

Palmore E (1999) Ageism: Negative and Positive, 2nd Edition, Springer, 280p.

Pasupathi M, Löckenhoff C (2002) Ageist behaviour. In: Nelson T (Ed) Ageism: Stereotyping and Prejudice Against Older Persons, 201-246. Cambridge, MA: Massachusetts Institute of Technology.

Robine JM, Cambois E (2013) Healthy life expectancy in Europe. Population \& Societies, 499, 4pp. https://www.ined.fr/en/publications/editions/population-and-societies/healthy-life-expectancy-europe/

Sanderson WC, Scherbov S (2007) A new perspective on population aging. Demographic Research 16(2): 27-58. https://www.demographic-research.org/volumes/vol16/2/16-2.pdf

Sanderson WC, Scherbov S (2008) Rethinking Age and Aging. Population Bulletin 63(4): 1-16. http:// pure.iiasa.ac.at/id/eprint/8470/

Sanderson WC, Scherbov S (2015) Faster Increases in Human Life Expectancy Could Lead to Slower Population Aging. PLoS ONE, 10(4): e0121922. http://pure.iiasa.ac.at/id/eprint/11473/

Singer J (1998) Using SAS PROC MIXED to Fit Multilevel Models, Hierarchical Models, and Individual Growth Models. Journal of Educational and Behavioral Statistics, 23(4): 323-355. https://www. ida.liu.se/ 732G34/info/singer.pdf

Shiovitz-Ezra S, Shemesh J, McDonnell/Naughton M (2018) Pathways from Ageism to Loneliness. In: Ayalon L, Tesch-Römer C (Eds) Contemporary Perspectives on Ageism. International Perspectives on Aging, vol 19. Springer, Cham https://link.springer.com/chapter/10.1007/978-3-319-738208_9\#citeas

Stypińska J, Nikander P (2018) Ageism and Age Discrimination in the Labour Market: A Macrostructural Perspective. In: Ayalon L, Tesch-Römer C (Eds) Contemporary Perspectives on Ageism. International Perspectives on Aging, vol 19. Springer, Cham https://ink.springer.com/chapter/10.1007/978-3-319-73820-8_6

Swift HJ, Abrams D, Marques S, Vauclair CM, Bratt C, Lima ML (2018) Agisem in the European Region: Finding from the European Social Survey. In: Ayalon L, Tesch-Römer C (Eds) Contemporary Perspectives on Ageism. International Perspectives on Aging, vol 19. Springer. https://link.springer. com/chapter/10.1007/978-3-319-73820-8_27

The 2018 Ageing Report, Economic \& Budgetary Projections for the 28 EU Member States (20162070) European Economy Institutional Papers, European Commission https://ec.europa.eu/info/ sites/info/files/economy-finance/ip079_en.pdf

United Nations, World Population Prospects (2019) https://population.un.org/wpp/Download/Standard/Interpolated/ 
Vauclair ChM, Lima ML, Abrams D, Swift HJ, Bratt Ch (2016) What Do Older People Think That Others Think of Them, and Does It Matter? The Role of Meta-Perceptions and Social Norms in the Prediction of Perceived Age Discrimination. Psychology and Aging, 31(7): 699-710. https://www. academia.edu/38092672/What_Do_Older_People_Think_That_Others_Think_of_Them_and_ Does_It_Matter_The_Role_of_Meta-Perceptions_and_Social_Norms_in_the_Prediction_of_Perceived_Age_Discrimination

van den Heuvel WJ, van Santvoort MM (2011) Experienced discrimination amongst European old citizens. European journal of ageing, 8(4): 291-299. https://www.ncbi.nlm.nih.gov/pmc/articles/ PMC3225618/

Voss P, Bodner E, Rothermund K (2018) Ageism: The Relationship between Age Stereotypes and Age Discrimination. In: Ayalon L, Tesch-Römer C (Eds) Contemporary Perspectives on Ageism. International Perspectives on Aging, vol 19. Springer, Cham https://link.springer.com/chapter/10.1007/978-3-319-73820-8_2\#citeas

\section{Data sources}

Human Mortality Database. https://www.mortality.org/

EUROSTAT Database. https://ec.europa.eu/eurostat/data/database

EUROSTAT, Gini coefficient of equivalised disposable income - EU-SILC survey (ilc_di12) http://appsso.eurostat.ec.europa.eu/nui/show.do?dataset=ilc_di12\&lang=en

Special Eurobarometer 296. Discrimination in the European Union: Perceptions, Experiences and Attitudes (2008) https://ec.europa.eu/commfrontoffice/publicopinion/archives/ ebs/ebs_296_en.pdf

Special Eurobarometer 378/EB76.2. Active Ageing (2012) https://data.europa.eu/euodp/cs/ data/dataset/S1002_76_2_EBS378

Special Eurobarometer 437/EB83.4 Discrimination in the EU in 2015 (2015) https://data. europa.eu/euodp/data/dataset/S2077_83_4_437_ENG

Unemployment statistics, Statistics explained, EUROSTAT (2019) https://ec.europa.eu/ eurostat/statistics-explained/index.php?title=Unemployment_statistics\#Longer-term_ unemployment_trends

Human Development Report 2016, UNDP, NY 10017 USA http://hdr.undp.org/sites/default/files/2016_human_development_report.pdf

\section{Information about the author}

- Jitka Rychtaříková, PhD, Professor, Department of Demography and Geodemography, Faculty of Science, Charles University (Prague). E-mail: jitka.rychtarikova@natur.cuni.cz 
Annex I. Macro-indicators of selected countries.

\begin{tabular}{|c|c|c|c|c|}
\hline Country & Macro-region & $\begin{array}{l}\text { Life expectancy } \\
\text { at age } 55 \text { both } \\
\text { sexes (e55), } 2015\end{array}$ & $\begin{array}{l}\text { Perceived start of } \\
\text { old age, } 2012\end{array}$ & $\begin{array}{l}\text { Human } \\
\text { development } \\
\text { index (HDI), } 2015\end{array}$ \\
\hline Austria & $\mathrm{W}$ & 28.3 & 61.9 & 0.893 \\
\hline Belgium & W & 28.2 & 67.9 & 0.896 \\
\hline Bulgaria & $\mathrm{E}$ & 23.3 & 63.8 & 0.794 \\
\hline Croatia & $\mathrm{E}$ & 25.0 & 62.9 & 0.827 \\
\hline Czechia & $\mathrm{E}$ & 25.9 & 59.5 & 0.878 \\
\hline Denmark & W & 27.7 & 64.3 & 0.925 \\
\hline Estonia & $\mathrm{E}$ & 26.3 & 62.4 & 0.865 \\
\hline Finland & $\mathrm{W}$ & 28.6 & 65.2 & 0.895 \\
\hline France & $\mathrm{W}$ & 29.9 & 65.9 & 0.897 \\
\hline Germany & $\mathrm{W}$ & 27.8 & 60.1 & 0.926 \\
\hline Greece & $\mathrm{W}$ & 28.3 & 65.7 & 0.866 \\
\hline Hungary & $\mathrm{E}$ & 23.7 & 58.0 & 0.836 \\
\hline Ireland & $\mathrm{W}$ & 28.4 & 64.2 & 0.923 \\
\hline Italy & $\mathrm{W}$ & 29.3 & 67.6 & 0.887 \\
\hline Latvia & $\mathrm{E}$ & 24.2 & 61.5 & 0.830 \\
\hline Lithuania & $\mathrm{E}$ & 24.3 & 65.3 & 0.848 \\
\hline Netherlands & $\mathrm{W}$ & 28.3 & 70.4 & 0.924 \\
\hline Poland & $\mathrm{E}$ & 25.7 & 62.8 & 0.855 \\
\hline Portugal & $\mathrm{W}$ & 28.5 & 67.9 & 0.843 \\
\hline Romania & $\mathrm{E}$ & 23.8 & 60.5 & 0.802 \\
\hline Slovakia & $\mathrm{E}$ & 24.8 & 57.7 & 0.845 \\
\hline Slovenia & $\mathrm{E}$ & 27.9 & 66.4 & 0.890 \\
\hline Spain & W & 29.7 & 65.5 & 0.884 \\
\hline Sweden & $\mathrm{W}$ & 29.0 & 66.6 & 0.913 \\
\hline United Kingdom & W & 28.3 & 61.9 & 0.909 \\
\hline \multirow[t]{3}{*}{ Sources: } & \multicolumn{2}{|l|}{ e55, year 2015; } & \multicolumn{2}{|c|}{ Human Mortality Database } \\
\hline & \multicolumn{2}{|c|}{ Perceived start of old age } & \multicolumn{2}{|c|}{ Special Eurobarometer 378/EB76.2. } \\
\hline & \multicolumn{2}{|l|}{ HDI } & \multicolumn{2}{|c|}{$\begin{array}{l}\text { Human Development Report 2016, } \\
\text { p.198 }\end{array}$} \\
\hline
\end{tabular}




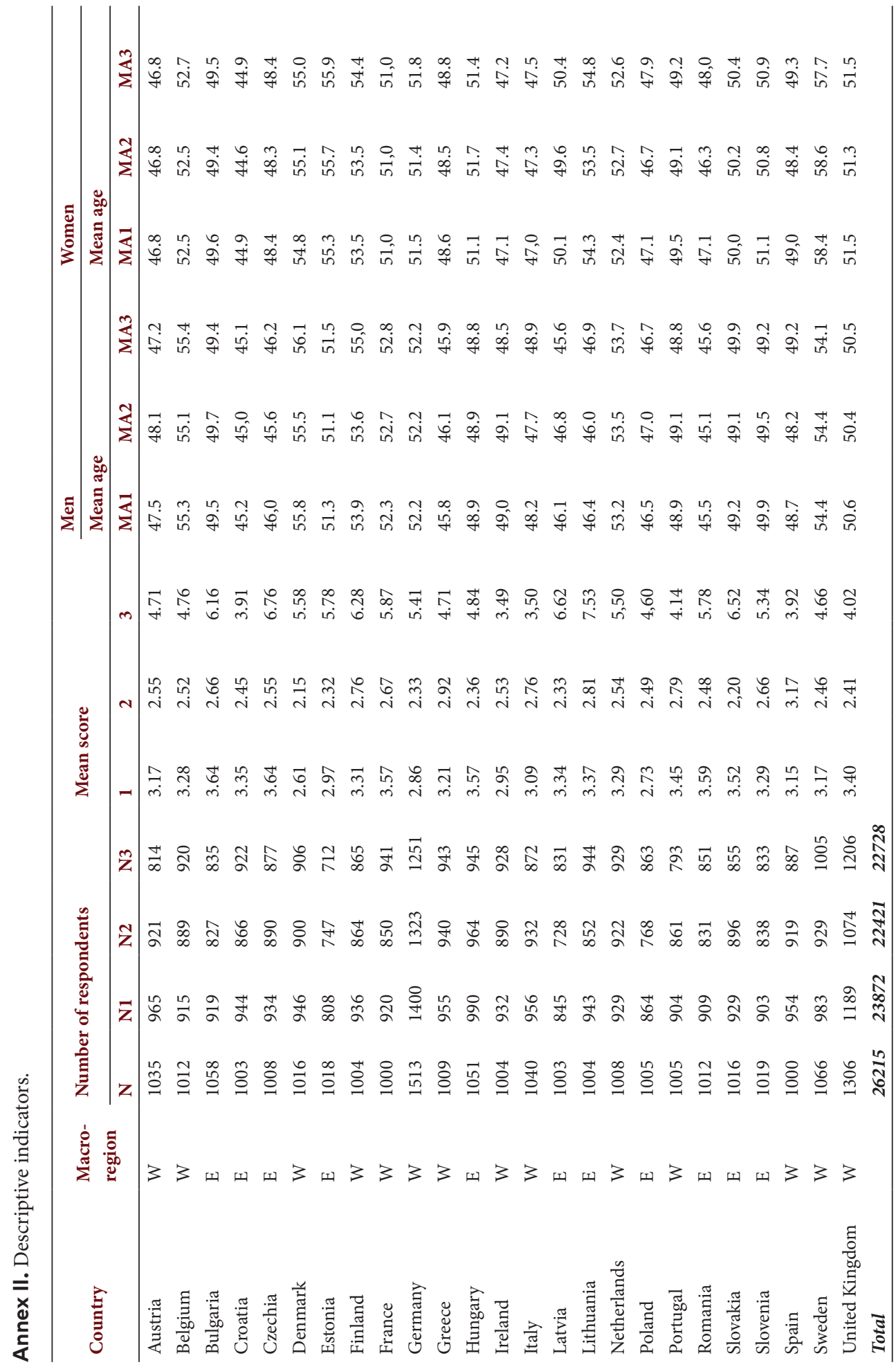




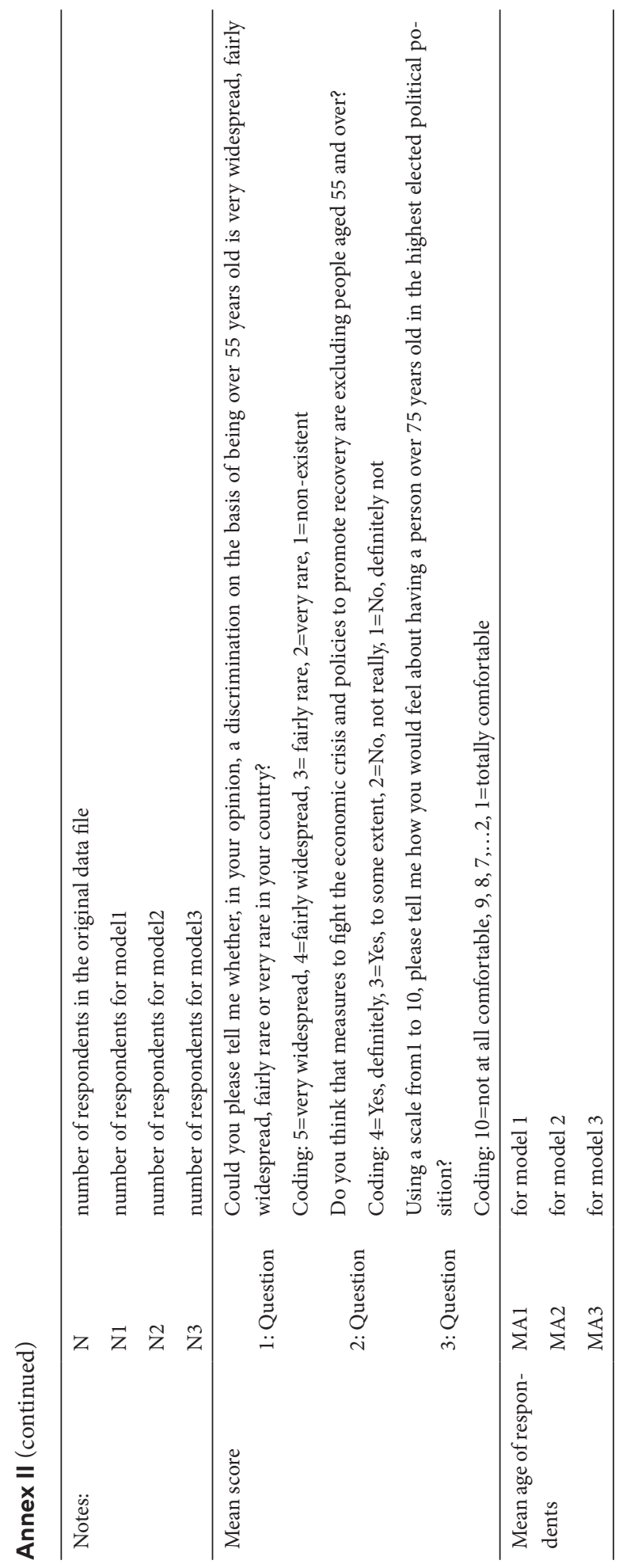

